\title{
La imaginación literaria en la vida pública*
}

\author{
MARTHA C. NUSSBAUM \\ Brown University, EE.UU.
}

La literatura y la imaginación literaria pueden tener un efecto subversivo frente a la idea de racionalidad expresada habitualmente por la ciencia econónica utilitarista. Por ello, la literatura debe formar parte de una educación en favor de una idea de racionalidad pública más amplia que la idea de individuo como maximizador de utilidades. A tra- vés del análisis de la novela de Dickens Tiempos difficiles, se llega a la conclusión de que sólo la imaginación proporcionada por las novelas - y no por los libros de economía política- puede ser la base para gobernar adecuadamente un país de personas libres e iguales o para desarrollar nuestra vida cotidiana como ciudadanos.

«Bitzer, dijo Thomas Gradgrind, «tu definición de un caballo",

«Cuadrúpedo. Herbivoro. Cuarenta dientes, nominalmente: veinticuatro muelas, cuatro colrnillos, y doce incisivos. Cambia de pelo en la primavera; en las regiones pantanosas cambian también sus pezuñas. Sus pezunas son duras, pero han de llevar herraduras. Se conoce su edad a traves de las marcas de su boca.* Así (y mucho más) continuó Bitzer.

CHARLES DICKENS,

Tiempos dificiles

Un niño me preguntó: ¿Qué es la hierba?, trayéndomela a manos llenas,

¿Como podría contestarle yo? Tampoco yo sé lo que es la hierba.

Imagino que debe ser el estandarte de mi ánimo, tejido de un verde esperanzado.

O puede que sea el pañuelo de Dios,

Un regalo de esencias, un recuerdo abandonado intencionadamente,

Llevando el nombre del dueño de algún modo en las esquinas, de modo que lo podamos ver y admirar, y decir ¿De quién?

\footnotetext{
* Este artículo fue publicado primero en inglés por la revista New Literary History (1991), 22, pp. 877-910. Agradecemos a los editores de dicha revista las facilidades dadas para nuestra version en castellano. El *Proemio* (1994) ha sido escrito por la autora especialmente para Isscon/A. La traduccion es de Elvira Barroso.
} 
O imagino que la hierba es también un niño, el recién nacido de la vegetación.

O imagino que es un jeroglífico uniforme;

$Y$ significa: surgiendo tanto en las regiones vastas como en las pequeñas,

Creciendo tanto entre los negros como entre los blancos,

Kanucks, Tuckahoes, congresistas, Cuffs, a todos doy por igual, $y$ a todos acojo de igual modo.

$\mathrm{Y}$ ahora me parece que es el hermoso cabello de los sepulcros.

Tiernamente habre de usarte, hierba rizada,

Puede que surjas del pecho de hombres jovenes,

Puede que de haberlos conocido, yo los hubiera amado,

Puede que vengas de gente vieja, o de vástagos arrebatados del regazo de sus madres,

$Y$ aquí tú eres el regazo materno.

Esta hierba es demasiado oscura como para surgir de las blancas cabezas de las viejas madres,

Más oscura que las barbas descoloridas de los ancianos,

Oscura como para surgir del desvaido rojo de los paladares.

WALT WHTMMAN, "Canto de mi mismo"

Hablando acerca de la discusión política en Norteamérica, Walt Whitman escribió que el artista literario es un participante imprescindible. El poeta es el "árbitro de lo diverso", el que equilibra su tiempo y su tierra. Su gran imaginación "ve la eternidad en los hombres y las mujeres" y "no los ve como sueños o motas». La llamada que hace Whitman a una poesía pública es, desde mi punto de vista, tan pertinente en nuestro tiempo como lo era en el suyo. En la vida política de nuestros días, con frecuencia carecemos de la capacidad para vernos unos a otros como enteramente humanos, como algo más que "sueños o motas". También con frecuencia esos rechazos de la compasión vienen acompañados y fomentados por una excesiva confianza en las formas técnicas de modelación del comportamien- 
to humano, especialmente aquellas que se derivan del utilitarismo económico. Estas técnicas pueden ser muy valiosas en su lugar apropiado, pero como guías de las relaciones políticas entre los ciudadanos muchas veces resultan incompletas. Sin la participación de la imaginación literaria, decía Whitman, "las cosas son grotescas, excéntricas, fracasos de sus potencialidades». Vemos que gran parte de las discusiones políticas de nuestros días son, de este modo, excéntricas y grotescas. El propósito de mi artículo (así como del proyecto más amplio del cual forma parte), es describir el ingrediente del discurso público que Whitman consideraba perdido en su Norteamérica, y mostrar los roles que podría desempeñar en el mundo contemporáneo. Este propósito surge de la convicción, que comparto con Whitman, de que la narración de historias y la imaginación literaria no se oponen a la discusión racional, sino que pueden proporcionar ingredientes esenciales para dicha discusión racional.

El proyecto despierta muchas cuestiones, algunas de las cuales he desarrollado en el artículo mismo; pero puedo anticipar al menos dos de ellas a estas alturas: la pregunta ¿por qué las novelas?, y la pregunta, igualmente importante, ¿qué novelas?

La pregunta acerca del "porqué" puede formularse desde varias perspectivas diferentes. La cuestión de por qué novelas y no tratados (especialmente tratados económicos) es un tema central en el artículo mismo, por lo cual no extenderé mi argumentación mayormente en este punto. Pero el lector puede querer saber por qué novelas y no otras formas de narrativa tales como historias y biografías. También cabría preguntarse ¿por qué novelas y no sinfonías o películas? Finalmente, si hemos de privilegiar los trabajos literarios de ficción, ¿por qué novelas y no tragedias o comedias o poemas líricos? Es un poco difícil hablar del "porquê» antes de saber el «qué»; esto es, antes de decir algo más acerca de la contribución de la obra literaria. Pero unas cuantas ideas generales comenzarán a orientar la discusión.

¿Por qué novelas y no historias o biografías? El tema central de mi artículo es la capacidad de imaginar lo que es vivir la vida de otra persona que, si se cambiaran las circunstancias, podría ser uno mismo o una de las personas queridas de uno. De manera que mi respuesta a la pregunta de la historia sale directamente de Aristóteles. El arte literario, decía, es «más filosóficon que la historia, porque la historia simplemente nos muestra alo que ocurrion, mientras que las obras de arte literarias nos muestran "las cosas del modo en cómo podrían haber sucedidos en una vida humana. En otras palabras, la historia simplemente registra lo que de hecho ocurrió, tanto si representa o no una posibilidad general para las vidas humanas. La literatura se centra en lo posible, invitando a sus lectores a preguntarse acerca de sí mismos. Aristóteles está en lo correcto. Al contrario que en la mayoría de las obras históricas, las obras literarias invitan a sus lectores a ponerse en el lugar de gentes de muy diversos tipos y a asumir sus experiencias. En los 
mismos modos en como se dirigen a sus lectores imaginarios, transmiten la sensación de que existen eslabones de posibilidad, al menos a un nivel muy general, entre los personajes y el lector. Las emociones y la imaginación del lector, en consecuencia, permanecen muy activos, y es la naturaleza de esta actividad y su relevancia para el pensamiento público lo que me interesa. Las obras históricas pueden, de hecho, producir formas similares de actividad, si están escritas en un estilo narrativo atractivo. Pero, en tanto en cuanto promocionan la identificación y compasión en el lector, se asemejan a las obras literarias, Y, ciertamente, sólo en raras ocasiones muestran el efecto de las circunstancias en las emociones y el mundo interior (lo cual constituye una parte central de la contribución de lo literario).

La pregunta acerca de por qué obras literarias y no obras en otros tipos de medios (como por ejemplo la música o la danza o el cine) es profunda y fascinante. Las obras en otros medios frecuentemente tienen propiedades narrativas y formas de expresividad emocional similares a las propiedades de lo literario que discutiré más adelante. Las obras musicales más serias tienen un contenido emocional expresivo. En algunos casos, resulta natural pensar que ese contenido presenta una forma narrativa, aun cuando uno es consciente de que cualquier representación verbal de esa narrativa es, en el mejor de los casos, una traducción vacilante. Análisis similares pueden darse con respecto al jazz. (Todo esto es de gran importancia en mi discusión de Dickens ya que la música es, en Tiempos dificiles, una fuente central de las imágenes de la sensualidad y el juego que constituyen el mundo del circo.) Por otra parte, esta contribución es, en su misma naturaleza, indeterminada, como un sueño, de una manera que limita su papel en la deliberación pública. Volviendo al cine, un reciente criticismo ha demostrado, convincentemente, que algunas películas tienen el potencial de realizar contribuciones similares a aquellas que yo atribuyo a la novela. Además, uno podría sostener, plausiblemente, que en nuestra cultura el cine ha suplantado, hasta cierto punto, a la novela como medio narrativo central, moralmente serio y, sino embargo, atractivo popularmente. Me parece que esto rebaja el poder constante de la novela, y continuaré sin excusarme defendiendo la novela como género vivo; pero no negaré tampoco que las películas puedan también contribuir a la vida pública de maneras similares.

Aquí yace el centro de mi respuesta a la cuestión de por qué las novelas y no otros géneros literarios: porque la novela es, desde mi punto de vista, una forma viva $y$, de hecho, sigue siendo la forma predilecta de ficción, moralmente seria y, sin embargo, popularmente atractiva, de las culturas europeas y americanas. Hay mucho que decir acerca de las tragedias clásicas que está íntimamente relacionado con lo que expondré aquí; pero si hemos de hablar de vida pública contemporánea y de los modos en que circunstancias concretas dan forma a las emociones y aspiraciones humanas, parece razonable que nos centremos en un género que aún si- 
gue siendo productivo, en donde las circunstancias concretas que son relevantes a nuestras deliberaciones puedan describirse. Ya he hablado de la poesía lírica, pero al volverme a Walt Whitman me estaba dirigiendo a un poeta cuya dedicación a la descripción, tanto narrativa como concreta, de diferentes modos de vida lo acercan en gran medida a la novela.

Esto me lleva a una cuestión más general acerca del género: la novela es concreta hasta un punto con frecuencia sin paralelo en otros géneros narrativos. Adopta como su tema, podríamos decir, la interacción entre aspiraciones generales humanas y formas particulares de vida social que $o$ bien permiten o bien impiden esas aspiraciones, y que las conforman poderosamente en el proceso. Las novelas (al menos las novelas realistas como la que voy a considerar) presentan formas persistentes de necesidad y deseo humanos, tal y como ocurren en situaciones sociales concretas. Estas situaciones frecuentemente, de hecho usualmente, difieren en gran medida de las del lector. Las novelas que reconocen este hecho, se dirigen y elaboran hacia un lector implicito, que comparte con los personajes ciertas esperanzas, miedos y preocupaciones generales humanas y que, debido a ello, es capaz de formar lazos de identificación y compasión con los personajes, pero que, al mismo tiempo, está situado específicamente en un plano diferente y necesita ser informado acerca de la situación concreta de los personajes. De este modo, la estructura misma de la interacción entre el texto y su lector imaginario, invita al lector a observar cómo los rasgos mutables de sociedad y circunstancia se sostienen sobre la realización de esperanzas y deseos compartidos (y también, de hecho, en su misma estructura). Este ir y venir entre lo general y lo concreto está construido en la estructura misma del género. De este modo, la novela elabora un paradigma de un estilo de razonamiento ético que es específico con respecto al contexto, sin llegar a ser relativista, en el cual obtenemos prescripciones concretas, potencialmente universalizables al trasladar una idea general de prosperidad humana a una situación concreta.

Esto me lleva a la pregunta: ¿qué novelas? Sostendré que el género en sí mismo, en virtud de algunos rasgos generales de su misma estructura, construye empatía y compasión de maneras muy relevantes para la ciudadanía. Aunque, por supuesto, no existe realmente un «género en sí mismo», sino sólo novelas, obras que no comparten un único cuerpo de rasgos a través de los siglos, aunque estén conectadas mediante una red de similitudes que se yuxtaponen. He elegido centrarme aquí en una novela realista inglesa, que tiene además temas políticos y sociales explícitos. Aunque en determinados aspectos hago una crítica del retrato de Dickens de las cuestiones sociales, me parece que su novela contiene (en su forma, así como en las afirmaciones contenidas en ella), consideraciones valiosas acerca del poder de la imaginación en política; consideraciones que están relacionadas con la riqueza metafórica y linguística de la novela. 
Pero las personas no pueden aprender todo lo que deberían aprender como ciudadanos simplemente leyendo obras situadas en un tiempo y un lugar distantes, no importa cuán aplicables universalmente sean muchas de las consideraciones de esas obras. Leer a Dickens nos enseña muchas cosas acerca de la compasión, pero no nos muestra las formas específicas en que muchas sociedades modernas inhiben la compasión hacia gentes de raza diferente, o religión o género o sexualidad. Ni muestra las maneras en que el odio de los grupos forma y deforma las vidas emocionales tanto del que odia como del que es odiado. Por consiguiente el proyecto más amplio del cual este artículo forma parte se vuelve, igualmente, hacia un grupo de novelas más contemporáneas relacionadas con estos temas.

Dos cuestiones deberían ahora enfatizarse. Primero, si bien voy a centrarme en la crítica de Tiempos difíciles a la economia, no considero mi propia investigación literaria como anticientífica o como una llamada a desautorizar la ciencia económica. Este propósito sería ridículo y fútil. Ni siquiera Dickens proponía esto. Para él deberíamos llegar a la Razón (por la cual entendía razonamiento científico formal) "a través de la suave luz de la Imaginación»; no propone que deberíamos confinarnos a la Imaginación y a vivir en el circo durante toda nuestra vida. En mi opinión, además, Dickens era, a pesar de esta concesión, demasiado hostil, globalmente, hacia la economía. Su hostilidad hacia la construcción formal matemática le impedía ver qué problemas, para los cuales buscaba una solución en la caridad privada, pudieran de hecho ser susceptibles de tener una solución pública institucional. Mi propuesta no es que desplacemos la ciencia económica, la cual puede hacer muchas cosas que la imaginación de los individuos no puede hacer sin esos modelos formales. Mi propuesta, por el contrario, es más modesta: que la ciencia económica se construya sobre datos humanos del tipo del que se revelan a la imaginación en novelas como Tiempos dificiles; que la ciencia económica persiga un grupo de fundamentos más complicados y adecuados filosóficamente.

En segundo lugar, mi acercamiento no está dirigido a desplazar la teoría moral y política, o a sustituir los argumentos basados en principios por emociones. Cualquier interpretación de este tipo sería profundamente contraria al espíritu e intención de este artículo. La experiencia del lector apunta en la dirección de ciertas teorías políticas en lugar de otras. Le resulta difícil justificar las formas más simples de utilitarismo, y se siente más a gusto con ciertos aspectos de las visiones kantiana y aristotélica del ser humano. Pero las diferencias sutiles entre esas teorías han de rechazarse mediante argumentos filosóficos. La lectura de novelas por sí sola no proveerá dichos argumentos.

Propongo dos cosas, por consiguiente, acerca de la experiencia del lector: primero, que proporciona consideraciones que deberían desempeñar un papel (aunque no como fundamentos ajenos a toda crítica) en la 
construcción de una teoría moral y política adecuada; segundo, que desarrolla capacidades morales sin las cuales los ciudadanos no tendrían éxito en alcanzar los resultados de cualquier teoría político-moral, por más excelente que ésta pueda ser. La lectura de novelas no nos proporcionará una visión completa acerca de la justicia social, pero puede servir como puente entre una visión de la justicia y la realización social de tal visión. El juez Oliver Wendell Holmes puede mostrarnos que «la vida consiste en pintar un cuadro, no en hacer una suma». El propósito de este artículo es elaborar tal idea y empezar a mostrar qué aspecto tiene un razonarniento público inspirado de tal manera.

Observando en sus hijos una abundancia imaginativa extraña e indeseable, un nocivo auge del sentimiento (en resumen, un desvío de la perfecta racionalidad científica de la que dependen tanto la vida privada como la pública, siempre que estén bien administradas), el señor Gradgrind, economista político, hombre público y educador, se pregunta por las causas:

«Acaso», dijo el señor Gradgrind reflexionando con las manos en los bolsillos y los cavernosos ojos en el fuego, "¿acaso algún profesor o criado les ha sugerido algo? ¿Acaso Louisa o Thomas han leído algo? ¿Acaso, pese a todas las precauciones, algún libro de cuentos fútil haya llegado a entrar en la casa? Porque, para mentes que han sido formadas prácticaniente en línea y en regla desde la cuna, esto es tan extraño, tan incomprensible» [p. 63].'

El señor Gradgrind sabe que los libros de cuentos no son meramente decorativos, ni simplemente entretenidos, aunque esto ciertamente bastaría para hacerle dudar de su utilidad. A su modo de ver, la literatura es subversiva. Es la enemiga de la economía política, que es como entiende el señor Gradgrind la ciencia. La literatura expresa en sus estructuras y modos de hablar un sentido de la vida que es incompatible con la visión del mundo contenida en los textos de economía política; y dedicarse a ella modela la imaginación y los deseos de tal modo que se subvierte la norma de la ciencia, la racionalidad. Es por buenas razones por lo que el señor Gradgrind enseña a Sissy Jupe, la chica del circo carente de educación, a considerar los libros de cuentos, que en otras ocasiones leía amorosamente a su padre, como "libros equivocados» (p. 99), sobre los que cuanto menos se dijera mejor. $Y$ es debido a esas buenas razones por lo que cae en una depresión acerca del futuro de la nación cuando se pone a considerar a los ciudadanos que, acudiendo en tropel a las bibliotecas públicas de Coketown «acogieron a DeFoe en sus regazos en vez de a Euclides y, en conjunto, parecían estar en su totalidad más cómodos con Goldsmith que con Cocker» (p. 90). Cuando los fútiles libros de cuentos entran en el hogar, la economía política peli- 
gra. El mundo se ve desde una perspectiva nueva, y las actividades que no están relacionadas con la economía, como el sentir o el fantasear, comienzan a aparecer representadas y, lo que es peor, comienzan a llevarse a cabo.

Sostendré a lo largo de este ensayo que el señor Gradgrind tiene razón: la literatura y la imaginación literaria son subversivas. El pensamiento literario es, en modos que aún han de especificarse, el enemigo de cierta clase de pensamiento económico. Hasta ahora solíamos considerar la literatura como algo opcional: como algo genial, valioso, entretenido, pero que existe al margen del pensamiento político, económico y legal, en algún otro departamento de la universidad, más bien de orden secundario. La segmentación de la academia moderna (así como estrechas teorías hedonistas acerca del valor literario) nos han hecho perder la visión que el señor Gradgrind seguramente poseía: que la novela (ya que por el momento me centraré en este género) es una forma moralmente controvertida, que expresa en su misma forma y estilo, en sus modos de interacción con el lector, un sentido normativo de la vida. Insta a los lectores a advertir esto y no aquello; a ser activo de ciertas maneras y no de otras; le guía, en definitiva, hacia ciertas posturas de la mente y el corazón y no a otras. Y, como el señor Gradgrind demasiado claramente comprendió, éstas son las formas inadecuadas, las posturas altamente peligrosas desde el punto de vista de la estrecha concepción de la racionalidad económica (que constituye, en la opinión de Gradgrind, la normativa tanto para el pensamiento privado como para el público).

Pero si la literatura es, desde el punto de vista económico-político, algo peligroso que merece ser suprimido, esto implica también que no es un mero ornamento y que tiene potencial para contribuir de una manera distintiva a nuestra vida pública. Y si alguien tuviera dudas acerca de los textos de economía política (con respecto a su adecuación como visiones de la humanidad, expresiones de la vida social humana en un sentido completo), uno podría ver en el celo del repudio del señor Gradgrind una razón suficiente para querer traer a casa los libros de cuentos fútiles, para que puedan así defender su causa. Y si la defendieran de modo satisfactorio, tendríamos entonces razones de peso para invitarles a que se queden en ella; no sólo en nuestros hogares y escuelas, dando forma a las percepciones de nuestros hijos, sino también en las escuelas de gestión política pública y oficinas gubernamentales, y en nuestros tribunales e incluso escuelas de derecho (es decir, allí donde quiera que nuestra imaginación pública se educa y nutre), como piezas centrales de una educación en favor de una racionalidad pública.

Me centraré, por tanto, en las características de la imaginación literaria como imaginación pública. Una imaginación que guiará a jueces en su juzgar, legisladores en su legislar, gestores o ejecutivos de los bienes públicos en su auscultar la calidad de vida de la gente, tanto de cerca como de lejos. En otro contexto he sostenido que la novela forma una parte ineludi- 
ble de la reflexión personal y también inicié la tarea de encomendarla a la esfera de lo público. ${ }^{2}$ Esta es una tarea difícil, ya que, para muchas personas, la literatura puede resultar esclarecedora en cuestiones relativas a la vida personal y a la imaginación privada, pero resulta vana y fútil cuando se trata de preocupaciones más substanciosas como las clases y las naciones, para las que, parece ser, necesitamos algo más seguro científicamente, más imparcial, desligado, más severamente racional. Sin embargo, es mi intención sostener ahora que ahí, en mayor medida si cabe, las formas literarias pueden hacer una contribución ineludible y distintivamente valiosa. Defenderé esta causa concentrándome, por encima de todo, en la novela, como ya he señalado, y, en particular, en la obra de Dickens Tiempos dificiles, que tiene como tema central la contribución de la novela a la vida moral y política, tanto representando como llevando a cabo el triunfo de la novela sobre otras formas de imaginar el mundo. El adversario en este caso no van a ser ciertas formas filosóficas sofisticadas de utilitarismo, ni tampoco la economía política de los grandes economistas filosófico-políticos como Adam Smith, sino la forma más burda de utilitarismo económico, que de hecho se emplea en muchas áreas de la gestión pública y que se recomienda como norma para muchas otras. (Más adelante ilustraré este extremo con ejemplos que proceden de baremos para medir la calidad de vida en la economía del desarrollo.) Me centraré, por encima de todo, en la cuestión de la medición del bienestar de la población, que resulta ser uno de los temas centrales de Tiempos dificiles, así como un escenario excelente en donde observar el contraste entre lo económico y lo literario en plena acción. Cuestionaré qué clase de actividades de la personalidad son mejores para esta tarea, qué pensamientos, qué sentimientos, y qué modos de percepción. Esto nos llevará, naturalmente, a la cuestión de qué textos representan estas actividades deseadas y las hacen surgir.

Mi pregunta, entonces, no es sólo acerca de lo que la novela representa, lo que está dentro de ella. Éste es un aspecto importante de mi proyecto. Pero quiero preguntar también qué sentido de vida incorpora en su forma misma: no sólo de qué manera los personajes sienten e imaginan, sino qué clase de sentir e imaginar se lleva a cabo al contar la historia misma, en la forma y en la textura de las palabras, en el modelo narrativo, en el sentido de vida que anima el texto en su totalidad. Y preguntaré también, e inevitablemente, qué clase de imaginar y de sentir surge de la forma del texto mientras se dirige al lector imaginado; qué clase de actividad lectiva se construye desde su forma. ${ }^{3}$ Por tanto, cuestionaré no sólo la oposición en Tiempos dificiles entre Gradgrind y M'Choakumchild por una parte, y Sissy Jupe y el circo por la otra, sino también los modos en que las frases y capítulos de la novela misma, asi como la acción de leerla, llevan a cabo triunfalmente su exuberante rebelión contra la economía política ${ }^{4}$ y contra los «libros azules de cifras" en que esta visión del mundo humano está codificada. 


\section{Nada salvo los hechos}

Tiempos dificiles de Charles Dickens contiene una visión normativa de cierta economía política científica y de la imaginación política científica. El texto presenta esta normativa como blanco de un ataque satírico fulminante; objetivo éste que no se puede describir verdaderamente si no se le hace aparecer como algo ridículo y siniestro. Pero ya que el ataque es un ataque profundo, el blanco satírico mismo se describe con cierta reflexión, mientras la novela representa y muestra la significación más profunda de lo que todavía en nuestros días se enseña como normativa con respecto a la gestión política pública, el bienestar y el desarrollo económico, y, recientemente, incluso el derecho. Lo que resulta extraño de esta norma para el lector de la novela es el hecho de que el autor se la tome en serio hasta el final; es decir, la normativa es entendida no sólo como un medio para redactar informes, sino como una manera de interactuar en los encuentros cotidianos; no sólo como un modo de hacer negocios, sino como una manera de definir un caballo o hablarle a un niño; no sólo como un medio para parecer respetable profesionalmente, sino como un compromiso que determina todo el contenido de la vida personal y social de uno. Pero debido a que esta norma tiene una pretensión de racionalidad (por encima de su mera utilidad profesional), y a que si se trata realmente de una norma sería justo pedir a la gente que se atuviera a ella constantemente, parece razonable examinarla de este modo, preguntándose cómo serían las personas que, real y concienzudamente, entienden el mundo del modo en que esta normativa sugiere, y si acaso esa visión del mundo es total. ( $Y$ también parece razonable suponer que la visión personal, así como la conducta de científicos comprometidos socialmente, viene influida, de hecho, por el contenido, al menos hasta cierto punto, de la normativa que su ciencia sostiene, por los hábitos de percepción y reconocimiento que alienta. De manera que, examinándola de este modo, podemos probablemente aprender algo acerca de lo que hacemos $a$ los demás cuando la sostenemos como norma, y lo que nos cabe esperar de los demás así tratados.) Dickens paga al utilitarista económico el tributo de que lo tomen por su palabra y de que le hagan atenerse a ella; en este sentido, poco, me parece a mí, puede quejarse. Más adelante esbozaré algunas conexiones explícitas entre la filosofía de Gradgrind y algunos aspectos del pensamiento y la práctica económica contemporánea. Por ahora, lo que he de hacer es establecer el perfil de esta normativa, tal y como la disecciona la novela. (Esto significará comenzar a hablar también de sus limitaciones, ya que estudiándolas, podremos observar lo que la novela ve.)

Lo que estoy a punto de decir en este texto puede parecer obvio en muchos aspectos, ya que forma parte del diseño de la novela el que el modo de pensar del economista, considerado en el contexto total de la vida diaria, 
resulte extraño, y el modo de pensar opuesto parezca natural. Sin embargo, lo que quiero recoger en este ensayo, precisamente, es que el oponente económico no es un hombre de paja, sino que representa una concepción dominante en la esfera pública, incluso en nuestros días, y que se presenta en una forma no muy diferente a la que aparece en esta novela. En una ocasión, centrándome en las modificaciones sutiles del utilitarismo que pueden encontrarse en la filosofía reciente, ${ }^{5}$ me pareció que la sátira de Tiempos difíciles era injusta. Pero tras haber dedicado algún tiempo al mundo de la economía (ver sección IV), leyendo la prosa económica y siguiendo sus argumentos, estoy convencida de que el criticismo en la novela es tanto justo como imperativo. La simple idea utilitarista de en qué consiste la elección racional domina, no solamente el pensamiento y la práctica económica, sino también a un número considerable de textos en otras ciencias sociales (dado el prestigio que la economía tiene en las ciencias sociales), en donde la "teoría de elección racional" se considera equivalente a la teoría de la elección racional utilitarista que se emplea en la economía neoclásica. Los gestores de la política pública se vuelven hacia esas teorías para buscar una manera ordenada, adecuada de tomar decisiones. Y el aura de elegante simplicidad de la teoria es $\tan$ grande que está adquiriendo una influencia creciente incluso en el derecho, el cual, tradicionalmente, ha razonado de maneras muy diferentes, usando una norma diferente de lo racional. ${ }^{6}$ Recientemente, esta teoria se ha abierto camino incluso en los estudios de literatura, en donde el prestigio de la economía neoclásica (al estilo de la escuela de Chicago) se recupera para defender una amplia aplicación de su teoría de la conducta, a todas las áreas de la vida humana. ${ }^{7}$ Para el lector que no está familiarizado con la posición opuesta, ni con su prosa, un curso breve acerca de los trabajos de Gary Becker y Richard Posner sería muy recomendable (ya que sus puntos de vista son extremos, pero sólo en el sentido de que, al igual que esta novela, ellos emplean una teoría que la economía trata como normativa para la elección racional en general. Si realmente es una norma de racionalidad tienen derecho a emplearla, con lo cual, estaremos entonces justificados para examinar sus trabajos como posibles muestras de la adecuación normativa de la teoria). ${ }^{8}$ Al lector dejo, entonces, la tarea de investigar más allá la posición del economista en la vida contemporánea, ya que quiero ahora dirigir mi mirada al señor Gradgrind, quien al menos acaba la novela expresando cierto remordimiento, revelando así cierta complejidad humana.

«En esta vida, no queremos nada salvo los Hechos, señor; nada salvo los Hechos" (p. 47). Esta exigencia famosa, anunciada en las clases de Gradgrind en el capítulo inicial de la novela (capítulo titulado «La única cosa necesarian), muestra la esencia de la filosofía de Gradgrind. La novela caracteriza, poco después, esta filosofía aún más hablando por boca del señor Gradgrind mediante una serie de oraciones encaradas y francas, que parecen expresar perfectamente la calidad de su mente: «Thomas Gradgrind, señor. 
Un hombre de realidades. Un hombre de hechos y de cálculos. Un hombre que procede mediante el principio de que dos y dos son cuatro, y nada más, $\mathrm{y}$ al que no debe intentar convencerse de que puede haber algo más. Thomas Gradgrind; sí, señor - perentoriamente Thomas- Thomas Gradgrind. Con una regla y un par de balanzas, y la tabla de multiplicar siempre en su bolsillo; sí, señor; listo para pesar y medir cualquier pedazo de naturaleza humana y decirle exactamente a qué se reducen. Es una mera cuestion de números, un caso de simple aritmética» (p. 48). La economía política de Gradgrind pretende ser una ciencia, pretende ofrecer hechos en lugar de fantasías fútiles, objetividad en vez de meras impresiones subjetivas, la precisión del cálculo matemático en lugar de la intratable elusividad de las distinciones cualitativas. "La razón es (como usted sabe)», indica a Bounderby, "la única facultad a la que la educación debe dirigirse» (p. 62). Y la economía de Gradgrind pretende, orgullosamente, acercarse al mundo con la razón en lugar de con el sentimiento (y con el poder calculador e independiente teóricamente del intelecto matemático, en vez de con alguna forma de reflexión de un tipo más cualitativo). El intelecto de Gradgrind entiende el mobiliario hetereogéneo del mundo, incluidos los seres humanos, como superficies o «pedazos» que han de ser medidos o pesados.

En esta breve descripción encontramos cuatro aspectos de la mentalidad utilitaria, nítidamente empaquetados. ${ }^{9}$ En primer lugar, reduce las diferencias cualitativas a diferencias cuantitativas. En lugar de Louisa, Tom, Stephen y Rachel, con toda su compleja diversidad cualitativa y sus particularidades históricas, tenemos simplemente tal y tal "pedazo de naturaleza humana» cuantificable. Esta supresión de la diferencia cualitativa se lleva a cabo por un proceso de abstracción de todo lo que hay en una persona que no pueda ser reducido a una fórmula matemática. De manera que esta mentalidad, para poder medir lo que mide, atiende sólo a una versión abstracta y muy general del ser humano, en lugar de atender a la diversidad de lo concreto con que la novela nos confronta. Vemos funcionar esta mente matemática abstrayente en la escuela de Gradgrind, en su trato a los estudiantes, cuando los llama por números ("Chica número veinte»), en lugar de por sus nombres, así como al verlos como en sun plano inclinado de pequeños recipientes bien ordenados, lisos para recibir toneladas de hechos, vertidas sobre ellos hasta que estén llenos hasta los topes» (pp. 47-48). Vemos funcionar esta mente matemática en el tratamiento a los trabajadores de Coketown como tantas y tantas "manos y estómagos» (pp. 102-103), como "torrentes de individuos" cuyos destinos podían calcularse en la pizarra (pp. 131-132), cuyas diferencias cualitativas eran tan irrelevantes como las de alas hormigas y escarabajos» "entrando y saliendo de sus nidos». ${ }^{10}$

En segundo lugar, la mentalidad de Gradgrind, inclinada al cálculo, está determinada a agregar los datos obtenidos de las vidas individuales y acerca de ellas, para llegar a un cuadro de total utilidad que borre la inde- 
pendencia, asi como la diferencia cualitativa. ${ }^{11} \mathrm{El}$ individuo no llega siquiera a ser tan único como un insecto, ya que en el cálculo del señor Gradgrind se convierte en un simple input dentro de una compleja operación matemática, que trata la unidad social como un único gran sistema, en donde las preferencias y satisfacciones de todos se combinan y funden. Así en la educación de Louisa, las clases trabajadoras se convierten en:

Algo para trabajar tanto y ser pagados tanto, y ahr acaba; algo que ha de ser establecido de manera infalible por las leyes de la oferta y la demanda; algo que tropezó contra esas leyes y se rebozó en la dificultad; algo que era una pizca cuando el trigo era escaso, y que se atracó cuando estaba barato; algo que se incrementó en tal tasa de porcentaje, y cedió un porcentaje equivalente en crimen y tal otro porcentaje en pobreza; algo al por mayor, del cual se amasaron las grandes fortunas; algo que ocasionalmente crecio como el mar, e hizo algún daño y fue un desperdicio (sobre todo para sí mismo), y volvio a caer; esto sabia ella que eran las manos de Coketown. Pero difícilmente habia ella pensado en separarlas en unidades, al igual que nunca pensó en separar el mar a gotas [pp. 187-188].

Las vidas son gotas en un océano sin demarcaciones, y la pregunta acerca de cómo está saliendo adelante el grupo es una cuestión cuya resolución económica exige que desaparezcan la vida y las acciones distintivas de cada uno. ${ }^{12}$

El señor Gradgrind no consigue todo su objetivo en su escuela, en donde sus estudiantes, aunque se numeren en lugar de nombrarse, retienen sus distintos grados de rendimiento, sus capacidades para pensar y hablar como núcleos de elección independientes, e incluso cierta medida de distinción cualitativa. $\mathrm{Ni}$ tampoco consigue su objetivo totalmente, podemos observar, en relación a sí mismo, ya que su retórica interna, en el pasaje citado, insiste en la separatividad y diferencia cualitativa de su propia mente con respecto a la de los otros: «Podrían ustedes esperar introducir absurdas creencias en la cabeza de George Gradgrind, o Augusto Gradgrind o John Gradgrind o Joseph Gradgrind (todas ellas personas ficticias y supuestas), pero no en la cabeza de Thomas Gradgrind, ¡no, señor!" (p. 48). Es un punto sutil en la novela el que el grado de autonomía personal y autorrespeto que el señor Gradgrind desea para sí mismo, exija que se contemple con una distinción que niega en sus cálculos, y le permita, incluso, la creación de cierta (extraña y burda) ficción. ${ }^{13}$

Pero con su familia directa le va mejor, ya que se las arregla para tratar a sus propios hijos, en mayor o menor medida, como la economía política recomienda. ${ }^{14}$ Cuando Louisa, en plena agonía acerca de su inminente matrimonio con Bounderby, estalla en sollozos: «Padre, a menudo he considerado que la vida es muy corta», su desconcertado padre le responde: 
«Sin duda es corta, querida mfa. Sin embargo, está comprobado que la duración media de la vida humana se ha incrementado en los últimos años. Los cálculos de varias compañías de seguros y cajas de pensiones, entre otros cálculos que no pueden equivocarse, han sentado este hechon.

"Yo hablo de mi propia vida, padre".

"Ah!, ¿si? Pues aun asi", respondio el señor Gradgrind, "no necesito señalarte, Louisa, que [tu vida] está gobernada por las mismas leyes que gobiernan las vidas en su conjuntos [p. 135]. ${ }^{15}$

$Y$ en uno de los momentos más escalofriantes y brillantes de la novela, podemos ver lo que supondría verse a uno mismo a través de los ojos de la economía política. La señora Gradgrind, sumisa y teniendo siempre una vaga idea tanto de su propia distinción cualitativa y de sus límites separados, como de su acción independiente, yace en el que pronto será su lecho de muerte. " ¿Sufres mucho, madre querida?" ", pregunta Louisa. La respuesta no se hace esperar. "Creo que existe cierto dolor en algún lugar de esta habitación", respondió la señora Gradgrind, "pero no me atreveria a decir, positivamente, que lo tengo yo" "(p. 224). La economía política sólo ve dolores y satisfacciones, y su presencia en general; pero no puede ver a las personas como núcleos delimitados distintivos de satisfacción o sufrimiento, ni mucho menos como agentes cuyo plan de acción es esencial para la humanidad de aquello que se desea obtener. La señora Gradgrind ha aprendido bien su lección.

Si volvemos ahora a la descripción inicial del señor Gradgrind, vemos en él un tercer rasgo de la mentalidad económico-política: su determinación a encontrar una solución clara y precisa para cualquier problema humano. ${ }^{16}$ El señor Gradgrind, si recordamos, está preparado "para pesar y medir cualquier pedazo de naturaleza humana, y deciros exactamente su valor» (p. 48). Y su despacho es descrito más adelante como «un apartamento encantador» en donde «las cuestiones sociales más complicadas fueron sumadas, totalizadas y finalmente asentadas» (pp. 131-132). Debido a que ha sumado los datos humanos desde el principio de "manera tabular», la mentalidad económica cree fácil entender las vidas de los seres humanos como un problema matemático (relativamente elemental) que tiene una solución definida, ignorando por completo el misterio y la complejidad que existe en cada vida, en la intriga y el sufrimiento de las elecciones que se toman, en sus amores enrevesados, en sus intentos de afrontar la misteriosa y terrible realidad de su mortalidad. ${ }^{17}$ La optimista mentalidad calculadora de hechos, gira alrededor de las superficies de esas vidas como si no tuviera necesidad de mirar dentro de ellas; como si realmente pudiera «establecer todos sus destinos en una pizarra" (p. 132). A los hijos e hijas de Gradgrind se les enseña, desde muy temprano, a enfrentarse al mundo de la naturaleza sin ningún sentido de lo misterioso, de lo asombroso, de la profundidad. De este modo, no resulta chocante la definición de Bitzer de un caballo, que representa una 
descripción marcadamente uniforme, abstracta, de los rasgos superficiales de dicho animal, rehusando imaginar tanto su propia forma de vida compleja, como su significación para la vida de los humanos que los quieren y que se ocupan de ellos. Así pasa también con los seres humanos. El señor Gradgrind no comprende el significado del desasosiego de su propia hija, cuando, de manera confusa, le habla de un fuego que brota en la noche y se asombra ante la brevedad de su propia vida (p. 135). Cuánto menos habría él de sentir cierto misterio y asombro ante aquellos distantes seres humanos que trabajan en las fábricas de Coketown. En una de las más sorprendentes reflexiones en primera persona de esta novela (cuya estructura narrativa describiré con más detalle posteriormente), este hábito de la mente es descrito y criticado:

Tantos centenares de Manos en este Telar; tantos centenares de Caballos de Vapor. Se sabe, a una libra de fuerza, lo que el motor rendirá; pero ni siquiera todos los calculistas de la Deuda Nacional son capaces de decirme la capacidad para el bien o para el mal, para amar o para odiar, para el patriotismo o para el descontento, para descomponer la virtud en vicio o al revés, en cualquier momento dado, en el alma de uno solo de estos callados siervos, con sus rostros impasibles y sus actos mesurados. No hay misterio en el motor; [pero] existe un misterio que permanccerá siempre insondable, incluso en el más insignificante de estos hombres. ;Imaginar que pudiéramos reservar nuestra aritmética para los objetos materiales, y gobernar estas terribles cantidades desconocidas por otros medios! [p. 108].

Si la economía política no incluye las complejidades de la vida moral de cada ser humano, sus esfuerzos y sus contrariedades, sus complicadas emociones, su perplejidad y su miedo; si no se puede distinguir en sus descripciones entre la vida humana y una máquina, entonces deberíamos sospechar de su capacidad para gobernar una nación de seres humanos. $Y$ deberíamos preguntarnos si, al entendernos como algo parecido a objetos inanimados, no será capaz de tratarnos con cierta falta de ternura.

$\mathrm{Y}$ esto nos lleva a la cuarta de la características de la racionalidad económica que nos presenta la novela. Al entender los seres humanos como contrincantes en un juego matemático y rehusar ver su misterioso mundo interior, la filosofía de Gradgrind es capaz de adoplar una teoría de la motivación humana que resulta elegante y simple, bien preparada para el juego del cálculo, pero cuya relación con respecto a las leyes más complicadas que gobieman el mundo interior de un ser humano han de ser contempladas con cierto escepticismo. De acuerdo a como Gradgrind se ve a sí mismo (hombre realista con los pies en el suelo, frío, de hechos en lugar de fantasioso), la teoría tiene un cierto aroma a realismo duro, que sugiere el desenmascaramiento de agradables, si bien etéreas, ficciones. Los seres humanos, nos dice esta visión carente de sentimientos, están motivados por el interés propio en todas sus acciones. ${ }^{18} \mathrm{El}$ tan perfecto 
alumno de Gradgrind, Bitzer, revela al final de la novela el principio bajo el que fue educado. Cuando el escarmentado señor Gradgrind intenta apelar a su gratitud y amor, Bitzer le detiene:

"Disculpad que os interrumpa, señor", respondió Bitzer, upero estoy seguro de que sabéis que todo el sistema social se basa en el interés propio. A lo que se ha de apelar es al interés propio de la persona. Es vuestra única posibilidad; así es como estamos constituidos. Fui educado en tal catecismo cuando era aún muy joven, señor, como supongo tendréis constancia" [p. 303].

Bitzer, el producto perfecto de la economía política, se niega a reconocer siquiera esos residuos de motivaciones de amor y altruismo que ahora inundan profundamente el corazón del propio señor Gradgrind. Porque esa es la filosofía en que fue educado, y esa filosofia conduce a raras e implausibles interpretaciones del mundo.

Muy pronto en la novela, cuando el padre de Sissy Jupe la ha abandonado y el primer impulso de ella es el de justificar su deserción con motivos altruistas, planes para el bien de ella, etc., Bounderby no lo aceptará en absoluto. Más vale que ella sepa, le dice, la dura y cruel realidad de su situación: ella ha sido, simple y llanamente, abandonada; su padre se ha dado, simplemente, el gusto de dejarla y ha salido huyendo. La novela, intencionadamente, deja este caso particular sin resolver; su función es la de subrayar diferentes supuestos de conducta, distintos modos de construir el mundo. La novela, en su conjunto, convence al lector (y al señor Gradgrind) de que Gradgrind se equivoca al negar la posibilidad de actuar altruistamente de manera genuina y en consideración a otro. Si existe esta posibilidad, entonces Bounderby ha interpretado la situación de Sissy apresuradamente y también de un modo poco generoso. Lo que se está sugiriendo es que el hábito del economista de reducir todo al cálculo, combinado con la necesidad de una teoría de la acción humana, produce una tendencia a ver el cálculo en todas partes, en lugar del compromiso y la solidaridad, la afinidad de sentimientos. «Desde el nacimiento hasta la muerte, cada instante de la vida humana consiste en un regateo sobre el mostradorn (p. 304). Esta tendencia conduce al análisis burdo y frecuentemente al error. Incluso cuando no conduce al error, conduce a una percepción egoísta de la gente y de los acontecimientos. Y, para colmo de males, enseñada desde una edad muy temprana reproduce en los pupilos su propia imagen.

En resumen; la pretensión de la economía política de que estén presentes todos, y exclusivamente, los hechos de la vida humana, debe ser contemplada con escepticismo, si por "hechos" queremos decir "verdades». Y su pretensión de defender la "razón» también debe observarse con escepticismo, si por "razón" entendemos una facultad en sí misma autocrítica y comprometida con la verdad. Los hechos de la economía política, en realidad, 
son percepciones reducidas e incompletas, y su "razón" es una operación dogmática del intelecto incompleta y poco digna de confianza en la mayoría de los casos. El intelecto que aprehende los hechos, se detiene en la superficie de los objetos sin obtener siquiera unos datos perceptuales adecuados: el despacho del señor Gradgrind se asemeja a un observatorio astronómico sin ventanas, en donde el astronomo ordena el mundo wexclusivamente mediante la pluma, la tinta y el papel» (p. 131), determinado a percibir sólo aquellos rasgos abstractos de la gente y de las situaciones que puedan traducirse fácilmente a cálculos económicos. Desde su punto de vista, él tiene razones positivas para escoger este procedimiento: en su determinación de ser realista y no sentimental, en su determinación de ser exacto, e incluso en su determinación de no dejarse influir por lo que pudiera parecer en un primer término. (Ya que el señor Gradgrind reconoce que Louisa «habría llegado a ser muy terca [...] de no haber sido por su educación», p. 57.) La novela nos permite ver esos fines positivos. ${ }^{19}$ Las propias oraciones que emplea muestran esa vocación de permanecer distante, realista y carente de prejuicios. Por ejemplo, en la franqueza de su forma cuadriculada, en su llaneza sintáctica, en su duro ritmo y musicalidad. (Hemos de señalar, sin embargo, que la prosa que la novela atribuye a la imaginación de Gradgrind es mucho más expresiva, más sucinta, más rítmica, más agradable en su extraña forma cuadriculada, que la simple inexpresividad de la prosa cargada de jergas que, de hecho, es usada por la mayoría de los economistas del tipo de Gradgrind. Dickens ha sido capaz de hacer del señor Gradgrind un personaje vivo en una novela legible en tanto en cuanto lo ha transformado.)

Pero la novela nos muestra que, en su determinación por ver sólo lo que puede caber en los cálculos utilitarios, la mente económica está ciega: ciega ante la riqueza cualitativa del mundo perceptible; ciega con respecto a la separatividad de sus gentes, a sus más íntimas profundidades, sus esperanzas, sus amores y sus miedos; ciega ante todo lo que supone vivir una vida humana y tratar de conferirle un significado humano. Ciega, por encima de todo, al hecho de que la vida humana es algo misterioso y a veces insondable; algo que exige ser tratado con facultades mentales y recursos del lenguaje que sean adecuados a la expresión de esa complejidad. En el nombre de la ciencia, el asombro que îlumina y urge a la ciencia más creativa y más profunda ha sido puesta en peligro. ${ }^{20} \mathrm{Y}$ lo que nos queda, simplemente, es una charada reductiva de la ciencia, en que una parte pequeña de la vida humana aparece en forma de números en la pizarra. Pronto nos encontraremos con las consecuencias políticas que trae consigo el confiar en tal cuadro.

Pero ahora deberíamos detenernos para preguntarnos acerca del tipo de escritura de que hace uso la novela, cómo difiere de los textos económicos del señor Gradgrind, y cómo su propio modo de imaginar y hablar determina la percepción del lector acerca de las cosas. 


\section{Meras fábulas acerca de hombres y mujeres}

Preguntémonos, pues, cómo difiere la novela de Dickens de los textos de economía política que el señor Gradgrind lee, con sus «principios tabulares» que miden el bienestar social. Hemos de empezar con los hechos más obvios, sin dar por sentado el hecho de que estamos leyendo un trabajo de un género distinto, sino cuestionando el género mismo; es decir, preguntándonos cómo da forma a la imaginación del lector y qué modo de vida expresa.

En primer lugar, pues, estamos leyendo una historia, que contiene personajes, hombres y mujeres en cierto modo como nosotros mismos. La historia presenta estos personajes, muy diferentes unos de otros, dotándolos de atributos morales y físicos que nos permiten distinguirlos entre sí. Se nos dice que atendamos a sus modos concretos de moverse y de andar, las formas de sus cuerpos, las expresiones de sus caras, los sentimientos de sus corazones. La vida interna de cada uno se presenta como si poseyeran tanto complejidad como profundidad psicológica propia. Vemos que, en cuanto que seres humanos, todos comparten problemas comunes y esperanzas comunes, así como que, por otra parte, se enfrentan a estas esperanzas y a estos problemas de formas diversas, en virtud de sus circunstancias concretas, según los recursos de que dispongan. Incluso los utilitaristas Bounderby y Gradgrind son seres humanos, ricos y complejos, cuya filosofia abstracta emerge de un mundo interior con el que no siempre, como estamos empezando a ver, están en armonfa. Las excepciones a esta regla general son la señora Gradgrind, tan débil que rinde los límites de su ser al cálculo económico, y, por encima de todo, Bitzer, el autómata pavorosamente vacio del cálculo utilitario. Bitzer es la excepción que cumple la regla; la excepción que nos invita a reconocer el aspecto real que tiene el retrato económico de la humanidad, cuando se lleva a cabo consistentemente sobre un ser humano en concreto. ${ }^{21}$ Vemos las reflexiones abstractas de la novela, pues, como si surgieran en cada caso de una vida humana concreta y como sí expresaran sólo una parte del contenido de la riqueza de esa vida interior. $Y$ aunque no siempre tengamos acceso explícito y constante a esa complejidad, estamos siempre autorizados a asombrarnos acerca de ella, a imaginarla (por ejemplo, imaginamos los motivos que conducen a Bounderby a negar sus orígenes y a la señora Sparsit a perseguir a Louisa; así como, con más simpatía, imaginamos, más adelante, el complejo desasosiego en el corazón del señor Gradgrind cuando le da la bienvenida al colapso de su sistema, con balbuciente remordimiento). Nos preguntamos cómo interpretar sus acciones, y nos lo preguntamos con una mezcla de compasión y criticismo que probablemente variará, en cierto modo, de lector a lector, así como varía la actitud de las personas hacia la gente en la vida real. (De esta manera, podemos discutir cuál es la 
interpretación correcta de cierto elemento en la novela, así como cuán justificables han sido nuestras simpatías, sin por ello olvidar la preocupación fundamental que nos reúne en cuanto que lectores.) La novela, en sus varias formas de hablarle al lector, reconoce estas cosas como relevantes, como dignas de atención y preocupación. Esto lo damos por sentado puesto que todos sabemos lo que es leer una novela y, sin embargo, no deberíamos. Por el contrario, deberíamos en todo momento ser conscientes de cómo nuestra atención y nuestro deseo son conducidos, y de qué manera tan diferente a como lo son en el curso de la lectura de un tratado acerca de la economía del bienestar.

Si queremos ser conscientes de esta conducción de una manera más gráfica, debiêramos centramos en nuestra relación, en cuanto que lectores, con el señor Gradgrind. Si el señor Gradgrind escribiera un libro de economía situándose en él como un agente consistente con su sistema, ¿qué sería interesante y sobresaliente del personaje de Gradgrind? ¿Cómo se dirigiria a la imaginación del lector? Claramente, sólo mediante el hecho de que su vida ha sido gobernada por las leyes que gobiernan las vidas del conjunto, y por el hecho de que él ejemplifica la, así llamada, racionalidad del regateador económico. Sólo bajo estas descripciones podría el señor Gradgrind aparecer en su propio libro. La «historia" de tal libro podría ser la historia de las transacciones, y su lector quedaría cautivado por él no por amor o miedo, sino por una mezcla de euforia intelectual y egoísmo racional. Tal es el contenido moral del género, si es que se trata de un género.

Qué diferente nuestra propia relación con el señor Gradgrind aquí. $¿$ Qué es, de hecho, lo que hace del señor Gradgrind un personaje interesante para el lector, un cautivador $\mathrm{y}$, al final de la obra, un personaje profundamente emotivo de un modo que Bitzer y Bouderby no pueden serlo? Seguramente, su fracaso como utilitarista consistente. Bitzer es sólo un tipo raro, no podemos identificarnos con él o preguntarnos acerca de él, ya que sentimos que todo en él está hueco. Una novela poblada enteramente por Blitzer sería como hacer ciencia ficción, y no absorbería al lector a la manera característica de la novela tradicional que se asienta en lazos de simpatía e identificación. Pero, por el contrario, nos encontramos adquiriendo cierto sentimiento de interés compasivo hacia el señor Gradgrind. La novela nos alienta a preguntarnos acerca de él, incluso a criticarle, a preocuparnos acerca de lo que le acontece. En resumen, a experimentarle como un personaje interesante y significativo dentro de una novela irresistible. Profundamente ligada a nuestra experiencia estética está la vocación por modelar el deseo.

¿Qué puede haber en el señor Gradgrind que despierte este deseo? Hemos de decir que se trata del hecho, descubierto bien al principio de la obra de que él no es consistente; está motivado por el amor, el compromi- 
so y una honestidad pura y simple, en modos que no encuentran expresión en su filosofía. Notamos cómo rehúsa apoyar el brutal desprecio de Bounderby al padre de Sissy. Somos conscientes de nobles motivos humanitarios que inspiran su preferencia por la razón sobre lo fútil; motivos que pueden estar mal orientados pero que, en sí mismos, son admirables. Y, por encima de todo, notamos tal grado de amor por su hija, tal dudar el llevar a cabo los planes que ha trazado para ella, que nos hace pensar que este hombre tiene un alma. Todo esto, quiero subrayar, esta fantasía y asombro, este respeto hacia el alma de la persona, está construido en el género mismo, en sus modos de dirigirse al lector. Sin un cierto número de personajes con los que podamos tener esta relación, perderíamos el interés y nuestro placer cesaría. Pero cuando nos incorporamos a tales relaciones estamos, desde el punto de vista de la economía política, actuando de modo incorrecto.

Esta novela nos narra una historia y, al narrarla, envuelve a los lectores con sus personajes, haciendo que se preocupen de sus proyectos, sus esperanzas y sus miedos, participando en sus intentos de desentrañar los misterios y perplejidades de sus vidas. ${ }^{22}$ La participación del lector se hace explícita a lo largo de numerosos puntos en la narración. Se hace ver a los lectores que la historia es, en cierto modo, su propia historia, mostrándoles posibilidades para la vida humana y elecciones de las que pueden, de algún modo, apoderarse. Así, se les anima a evaluar la historia y a interpretarla crítica y afectivamente, ya que el texto los considera agentes sociales responsables de la construcción de un mundo, que puede o no ser igual al mundo representado aquí. Agentes, que en la vida deben relacionarse emocional o prácticamente con los problemas de las clases trabajadoras, y con la conducta de administradores y líderes sindicales. Al imaginar cosas que no existen en la realidad, la novela, según su propia descripción, no está siendo «inútil», ya que ayuda a los lectores a reconocer su propio mundo y a elegir de manera más reflexiva en él.

En resumen, la lectura de esta novela genera, justamente (aunque en absoluto sea una sorpresa), las propiedades que imputa a la lectura de novelas en general, cuando (a través de los asombrados ojos del señor Gradgrind) describe la tendencia de la gente de Coketown a preferir leer una novela a las estadísticas del gobierno: «Ellos se preguntaban acerca de la naturaleza humana, de las pasiones humanas, de las esperanzas y temores humanos, las luchas, los triunfos y las derrotas, las preocupaciones, los gozos y las penas, las vidas y las muertes de los hombres y mujeres corrientes. A veces, después de quince horas de trabajo se sentaban a leer meras fábulas sobre hombres y mujeres, más o menos como ellos mismos, y niños más a menos como los suyos. Acogieron a DeFoe en sus regazos, en vez de a Euclides, y en conjunto parecían sentirse más cómodos con Goldsmith que con Cocker» (p. 90). Mientras el señor Gradgrind se asom- 
bra ante este "hecho disparatado", la lectora reconoce, por supuesto, que son sus propias preferencias y acciones actuales las que se están describiendo.

Hasta ahora hemos hablado de rasgos de la novela que son comunes a otros géneros de narrativa: su compromiso con la independencia y separatividad de las personas y con la irreductibilidad de la cualidad a la cantidad; su idea de que lo que les sucede a los individuos en el mundo es de una importancia enorme; su compromiso a describir acontecimientos de la vida no desde una perspectiva externa, como si estuviera describiendo las actividades de unas hormigas o de las partes de una máquina, sino desde dentro, como si poseyera las significaciones que los seres humanos confieren a sus propias vidas. La novela tiene un compromiso hacia la riqueza del mundo interior, mayor incluso que en otros géneros narrativos, así como un compromiso mayor hacia la relevancia moral de seguir una vida a lo largo de todas sus aventuras concretas en la totalidad de su mundo concreto. De este modo, se opone más profundamente que otros géneros al modo económico reductivo de ver el mundo, se compromete más profundamente a hacer distinciones cualitativas.

Pero mediante las meditaciones del señor Gradgrind acerca de los extraños hábitos de lectura de las clases trabajadoras de Coketown, accedemos a un rasgo de la novela que la separa, hasta cierto punto, de las novelas históricas, las biografías e incluso los dramas trágicos: nominalmente, su interés en lo corriente, en las vidas cotidianas y en las luchas de la gente común. Pensemos en los lugares que visitamos como lectores de esta novela: un aula, un hogar de clase media, un circo, un hogar de la clase trabajadora, la oficina de un administrador, una fábrica en donde se afanan los trabajadores, un pozo de mina abandonado en donde muchos trabajadores se han encontrado con la muerte. Ni uno solo de estos lugares habría sido escogido para albergar las tragedias de Sófocles o Racine. Incluso en los géneros de historia política y biografía las vidas de los muchos insignificantes pueden aparecer, al final, sólo como clases o estadísticas, de manera no muy distinta a como aparecen en los libros de economía política. Pero al leer esta historia nos abrazamos a lo común, que se ha convertido para nosotros en un objeto de nuestro interés y compasión. ${ }^{23}$ Visitamos esos lugares como amigos, preocupados acerca de lo que pueda pasarles. Y esto significa que poseemos ya, como lectores ( $y$ siempre que leamos con detenimiento) la experiencia moral de Louisa cuando visita la casa de Stephen Blackpool, y en la sacudida [moral] pierde todos los cálculos, al percibir que una Mano tiene un nombre, una cara, una vida diaria, un alma compleja, una historia:

Por primera vez en su vida entraba Louisa en una de las moradas de las Manos de Coketown. Por primera vez en su vida se hallaba cara a cara frente a cierta 
individualidad en conexión a ellas. Ella sabía de su existencia por centenares y por miles. Ella sabía qué cantidad de trabajo podía producir determinado número de ellas, en cierto periodo de tiempo. Las conocía en masa, entrando y saliendo de sus nidos, como si fueran hormigas o escarabajos. Pero a traves de sus lecturas sabía más de la vida de los insectos laboriosos que de estos hombres y mujeres trabajadores [p. 187].

Este es uno de los pasajes más poderosos y autorreferentes de la novela, ya que mucho después de la descripción de Stephen Blackpool, nos hace recordar que nuestra propia educación, así como nuestra experiencia como lectores, es, y ha sido, muy diferente de la educación, fundamentalmente económica, de los jóvenes Gradgrind. La persona educada exclusivamente en textos de economía no es alentada a pensar en los trabajadores como seres humanos complejos y completos iguales a ella, con sus propias historias, etc. La descripción de la clase trabajadora en la novela tiene fallas considerables. Existe cierta sentimentalidad; existe un extraño error de técnica literaria básica, cuando la misteriosa promesa de Stephen a Rachel no aparece jamás explicada y es imposible de descrifrar $y$, sin embargo, es la que determina toda la trama. Además, se desconfía tanto de todo grupo o acción colectiva, que el trabajo de los sindicatos está retratado de un modo manifiestamente injusto, incluso para los estándares de otros escritos realistas del mismo período del propio Dickens. ${ }^{24} \mathrm{Y}$, sin embargo, la idea esencial que contiene este parágrafo permanece: la novela nos hace reconocer la igualdad de la humanidad de miembros de clases diferentes a la nuestra. Nos hace reconocer a los trabajadores como sujetos reflexivos con complejas aspiraciones y sentimientos, y un mundo interior rico. Nos hace ver su pobreza, las condiciones opresivas de trabajo que tienen, en relación a aquellas aspiraciones y emociones. En definitiva, nos inspira compasión, asombro, y una vocación apasionada por la justicia. ${ }^{25}$

Si desde el punto de vista de Gradgrind las novelas consisten en mala economía, carentes de refinamiento matemático, desde el punto de vista de la novela la economía sofisticada es una mala novela: burda en su poder de representación y descripcion; falsamente independiente y alejada de las situaciones de los seres humanos; empobrecida en los sentimientos que reconoce e inspira. (Considérense también las historias que los personajes utilitaristas se cuentan a sí mismos, y que suponen ficciones tan burdas: el cuento de Bounderby - que roza el cliché - acerca del abandono y la autosuficiencia; la narración, carente de trama, de Gradgrind acerca de su victoria sobre George y Joseph y los otros Gradgrind; los libros fútiles sobre los "niños bien criados» y los «niños malcriados».) Este hecho dificilmente puede ser políticamente irrelevante, ya que lo que uno pueda hacerles a hormigas y escarabajos es, moralmente, completamente distinto a lo que uno puede hacerle a otro ser que goza de la dignidad y el misterio de la humanidad. Las atrocidades sociales que se realizan en la novela no 
están desconectadas de la visión de las Manos alimentada por la educación utilitaria (por la visión mecánica de Gradgrind; por la igualmente empobrecida visión del señor Bounderby para quien las Manos son todas iguales, ansiando comer sopa de tortuga y venado con cuchara de plata). Si se deshumaniza al trabajador en el pensamiento, es más fácil negarle a él o ella el respeto que toda vida humana merece.

El primer principio de la ciencia de la economía política según Sissy Jupe, la chica del circo que tristemente suspende la lección, es "Comportarse hacia los otros como yo querría que se comportasen conmigon (p. 95). (Con lo que el señor Gradgrind hace la observación «moviendo la cabeza con ademán negativo, de que todo esto estaba muy mal; de que indicaba la necesidad de seguir dándole vueltas al molino del conocimiento, a base de sistemas, cuadros sinópticos, informes, resúmenes, estadísticas ordenadas de la A a la Z», p. 96. ${ }^{26}$ Quiero sostener que el primer principio de Sissy Jupe no está meramente representado en esta novela, sino que está construido en su estructura misma como su principio guía. La novela nos invita a preocuparnos por los destinos de otros como nosotros, a los que nos ligamos tanto por una amistad compasiva como por una identificación empática. De manera que cuando la novela nos alienta al final a pensar lo que vamos a hacer, nuestra respuesta natural será, si hemos leído bien, obrar hacia otros hombres y mujeres corrientes como hacia nosotros mismos, contemplando al más pobre como alguien que podríamos ser nosotros, y viendo incluso en las circunstancias de vida más escuálidas y corrientes un lugar en donde, en la imaginación, hemos construido nuestra propia morada. ${ }^{27}$ (Y por «leer bien" no quiero decir que a uno se le ocurra una serie de juicios interpretativos en lugar de otros, sino algo más simple y más básico. Entiendo, simplemente, leer con cariño y asombro, preocupándose por los personajes, emocionándose con sus destinos. Esto es compatible con muchas otras interpretaciones. Pero, por supuesto, queda fuera el "leerles" con desdén, o entenderlos como inputs de una fórmula fija de antemano.)

Y esto me lleva a otro rasgo de la novela, del que hasta el momento no he comentado nada: su capacidad para proporcionar placer (ya que sus operaciones morales no son independientes de su excelencia estética, así como nos vincula a los trabajadores al hacer que nos sea grata su compañía). Una novela tediosa no tendría el mismo poder moral. $O$, más bien, el interés, en sí mismo un rasgo moral, precisa de la atención. Éste no es un aspecto incidental de Tiempos dificiles sino algo que se subraya de manera prominente en su modo autorreferencial. La antítesis del modelo moral de Gradgrind es el circo de Sleary, cuya capacidad de agradar está íntimamente ligada a su superioridad moral. Y si formulamos una vez más nuestra obvia pregunta acerca de cuáles son las diferencias entre esta obra y un texto de economía política, hemos de responder con toda seguridad que 
una de las más grandes la constituye el hecho de que este libro es entretenidísimo. Como el circo, la novela contiene humor, aventuras, sentido de lo grotesco, lo sorprendente, tiene música (nótese qué frecuentemente se emplean metáforas musicales), ritmo y movimiento. Su lenguaje es lírico y está lleno de figuras poéticas. Su trama es dramáticamente irresistible; sus personajes inspiran nuestra confianza y nuestra compasión, o nos hacen reír, o nos atemorizan, o nos enfadan o causan nuestro desdén (o alguna combinación compleja de algunos de estos). El placer que proporciona es, sin embargo, de una complejidad crítica y de una riqueza moral mayor que el que proporciona el circo, al que describe como intelectualmente incompletó, insistiendo en una mezcla compleja de narración de historias y de criticismo social que la novela está mejor capacitada para ofrecer. Pero en conjunto, la novela reconoce la importancia del arte, del juego de la imaginación, del placer de leer una buena historia.

La pretensión explícita de la novela es que éste es un aspecto importante del modo en como se capta la atención y el deseo del lector y, por tanto, una parte importante de la acción moral y política que expresa y genera. Como Sleary señala en dos ocasiones: "La gente tiene que divertirze». Sin distracciones la vida humana resulta monótona y mezquina, todo trabajar y usar, sin ningún disfrute intrínseco. La capacidad de este circo (esta novela) para jugar, para proporcionar goce (inseparable como en el circo del arte que transmite), ${ }^{28}$ es parte de lo que la hace una pieza fundamental de la vida humana, parte de la generosidad con la que habla a (y para) sus lectores. Porque expresa en su misma forma artística, el deseo de que el lector viva una vida de goce, de fantasía generosa y liberal, en vez de la vida de estrecha monotonía que sugieren las lecciones de economía política. ${ }^{29} \mathrm{Y}$ al formar con el lector una relación rica en placer, así como en reflejo moral, le enseña al lector un estilo de relación humana en donde la reflexión se nutre con la plenitud de lo caprichoso, y las actitudes morales se hacen más amables y generosas cuando la imaginación interviene. El lector de esta novela, de manera contraria a Louisa, «llega a la Razón a través de la dulce luz de la Fantasía». (p. 223); ésta colorea la razón, haciéndola, según la novela, más viva y más humana.

\section{Fantasia y prodigio}

Hemos hablado de la novela, de esta novela, como algo que incorpora en su forma un cierto tipo de visión político-moral radical, democrática, compasiva, comprometida con las diferencias cualitativas y complejas. Hemos dicho que no representa meramente un antagonismo entre la fantasía y la economía política, sino que la contiene en su misma estructura, en su modo de conversar con su lector hipotético. Pero ahora deberíamos tratar de profundizar más, tratar de decir más acerca de la imaginación misma 
que construye textos de ficción, del modo en que la novela la representa y ejemplifica. Por encima de todo, acerca de la fantasía, esa capacidad para ver una cosa como otra y una cosa en otra. Ya que es esta actividad de la mente la que la escuela de Gradgrind aborrece y desea extirpar por encima de todas; y es esta facultad la que la novela defiende de manera más central como necesaria para la buena vida, y ejemplifica de manera triunfante y exuberante en cada capítulo.

La fantasía es el nombre que emplea la novela para describir la capacidad de ver una cosa como otra, de ver una cosa en otra. Por tanto, podríamos también llamarlo la imaginación metafórica. Comienza, simplemente, como casi un reflejo instintivo de la mente (sólo Bitzer y Gradgrind carecen de él totalmente). Incluso Louisa, a quien se le ha prohibido que la cultive, ve formas en el fuego, confiere a patrones de percepción una significación que no está presente en la percepción desnuda misma de los sentidos. ${ }^{30}$ Las cosas parecen otras cosas o, más precisamente, las otras cosas se ven en las cosas inmediatas, cuando Louisa es al mismo tiempo consciente tanto de las imágenes conjuradas como del hecho de que no son realidades presentes. ${ }^{31}$ (Con el buen sentido que le es propio a la fantasía, ella no se precipita sobre el fuego para capturar las imágenes que ve en él. Un buen sentido, habría que añadir, del que su padre carece, que objeta a los dibujos de flores en la alfombra porque uno, usualmente, no las pisotea con las botas en la vida real. Sissy, por otra parte, sabe que esas flores, al ser flores de la fantasía, no podrian ser heridas por las botas de la realidad.) Entender la percepción, por consiguiente, como indicador de algo más allá de sí mismo; ver en las cosas que son perceptibles y están a mano otras que no están frente a nuestros ojos: esto es la fantasía, y por eso el señor Gradgrind la desaprueba.

En la infancia, la novela nos recuerda, esta habilidad se cultiva, usualmente, de múltiples formas mediante juegos, historias, canciones y nanas, los cuales están prohibidos en el esquema educativo de Gradgrind:

Ninguno de los pequeños Gradgrind había visto jamás una cara en la luna... Ninguno de los pequeños Gradgrind había aprendido ese estúpido pareado «Brilla, brilla, cstrellita; dime tú quién te fabrica». Ninguno de los pequeños Gradgrind se asombró ante tal asunto, ya que cada uno de los Gradgrind al llegar a la temprana edad de cinco años había ya diseccionado la Osa Mayor igual que el profesor Owen, y había conducido el Carro lo mismo que el conductor de una locomotora. Ninguno de los jóvenes Gradgrind había jamás asociado una vaca del campo con esa otra famosa del cuerno torcido, que empujó al perro que asustó al gato que mató a la rata que se comió la mata, o aquella otra, aún más famosa, que se comió a Pulgarcito. Ninguno de ellos había oído hablar de esas celebridades, y habían sido sólo presentados a la vaca como un rumiante cuadrúpedo, herbívoro, de varios estómagos [p. 54]. 
Desde el punto de vista de Gradgrind, de lo que se trataba era de omitir los detalles, dejando așí más espacio para el verdadero material de la educación. Pero la novela anuncia y muestra (como veremos), en su retrato de Thomas y Louisa, que esta omisión es la omisión de una habilidad moralmente crucial, sin la cual tanto las relaciones personales como las sociales se empobrecen. Cuando Louisa, vacía y sumisa, vuelve al hogar, la voz del autor le recuerda al lector la diferencia entre los recuerdos que ella guarda de su hogar y las influencias que el hogar y la imaginación de la infancia usualmente hacen surgir:

Tampoco ahora, al acercarse a su antigua casa, la invadían los dulces recuerdos que el hogar paterno nos hace evocar. Los sueños de infancia, sus alegres fábulas; sus ornamentos gráciles, bellos, humanos o imposibles, del mundo más allá: ¡Qué dulce haber cré́do cn ellos! ¡Qué dulce recordarlos cuando quedan atrás! Porque, entonces, el más insignificante de ellos surge como una gran Caridad en el corazón, en donde puedan refugiarse los pequeños y cuidar entre sus puras manos de un jardín en los pedregales del mundo, donde sería mejor si todos los hijos de Adán se solearan más a menudo, simple y confiadamente, sin astucias. ¿Qué tenía ella que ver con esto? Recuerdos de cómo había ella viajado hacia lo poco que sabía, a través de los encantados caminos de lo que ella y millones de criaturas inocentes habían esperado e imaginado; de cómo, tras llegar a la Razón mediante la suave luz de la Fantasia, la había visto como una diosa benevolente, respetuosa con otros dioses tan grandes como ella; no un ídolo severo, frío y cruel, con sus víctimas atadas de pies y manos, y su estúpida forma colosal erigida con una mirada glacial, que no ha de ser jamás movida por nada excepto una palanca que tenga en cuenta sus muchas toneladas de peso. ¿Qué tenía ella que ver con todo esto? [p. 223].

Aquí la novela establece una serie de complicadas conexiones, que la narrativa en su conjunto ya nos ha anticipado, y deberíamos detenernos a analizar. ¿Cuál es exactamente la relación entre la Fantasía y la caridad y la generosidad? ¿Qué tiene que ver con la compasión humana general y un uso benéfico de la razón?

El hombre en la luna, la vaca del cuerno torcido, la estrellita; en todos estos casos el niño imagina que una forma que la percepción presenta como un simple objeto físico, tiene una vida interior compleja, en ciertos modos misteriosa, en otros análoga a sí misma. Ver los cráteres de la luna como si se tratasen de los rasgos de una cara, hablarle a una estrella, contar la historia de una vaca, son cosas que la imaginación objetiva, independiente, de la ciencia económica no está dispuesta a hacer. Pero existe, como la novela se apresura a decir, cierta caridad en este querer ir más allá de lo evidente, y esta caridad es una preparación para caridades mayores en la vida.

Consideremos ahora qué es ver a un ser humano. La percepción representa a un objeto físico, posiblemente en movimiento. Tiene cierta for- 
ma, parecida a la que solemos atribuimos a nosotros mismos. Bien, ¿cómo sabemos realmente qué clase de objeto físico es éste, y cómo hemos de comportarnos con respecto a él? ¿Poseemos siempre una evidencia fidedigna de que no se trata de un robot muy sofisticado o de un autómata? $¿$ Posee realmente un mundo interior de la clase que se describe en las novelas? ¿Cómo saber realmente que ésta es una cara frente a nosotros y no, por ejemplo, un objeto mecánico complejo con cráteres, una máquina diabólicamente astuta? ¿Dónde obtener tal evidencia? En este sentido Dickens sugiere que toda vida humana es un ir más allá de los hechos, una aceptación de fantasías generosas, una proyección de nuestros propios sentimientos y actividades íntimas hacia formas que percibimos acerca de nosotros $y$ una recepción de esta interacción de imágenes de nosotros mismos, de nuestro propio mundo interior). Todos nosotros, en tanto en cuanto interactuamos moral y políticamente, somos proyectistas de fantasías, creadores y creyentes de ficciones y metáforas ${ }^{32}$ Pero el caso es, entonces, que la escuela de "hechos» (que niega la vida de vacas y caballos, así como la humanidad a los trabajadores), se dedica también a la creación de ficciones (tanto o más que los lectores de novelas y los fantasiosos), en sus firmes negativas a la vida y la humanidad que van más allá de los límites de lo evidente. Nunca sabemos con seguridad los contenidos de este corazón de forma percibida. Solamente tenemos la opción de elegir entre una construcción generosa y una construcción cruel. ${ }^{33} \mathrm{El}$ mirar al interior, o fantasía, la gran Caridad en el corazón, contribuye a una construcción generosa del mundo. Este construir no sólo es, como la novela sugiere, más adecuado como explicación total de la conducta humana, tal y como la experimentamos, ${ }^{34}$ sino también una consecuencia de modos de vida mejores.

Vemos la diferencia, por ejemplo, en las distintas maneras de considerar las motivaciones de los trabajadores: Bounderby ve sólo interés propio, mientras que la novela entiende una compleja variedad de motivos. La vemos en los modos en cómo se contemplan las posibilidades para el cambio político, ya que incluso cuando el mundo es un "pedregal", la Fantasía puede imaginar un jardín floreciente. La vemos también en el contraste entre las actitudes del circo y de Tom Gradgrind hacia los apetitos del cuerpo. La gente del circo es apasionada de una manera romántica y tierna, viendo siempre unos en otros vidas complejas, y entusiasmadas con ello. De Tom, la novela subraya con marcada ironía, que «era sencillamente inexplicable que un joven caballero, cuya imaginación ha sido estrangulada en la cuna, pudiera aún ser perturbado por su fantasma en la forma de sensualidades serviles» (p. 165). Considerar a los cuerpos como objetos físicos en movimiento, contribuye al empobrecimiento de la vida sexual. No es casual que los utilitaristas sean retratados a lo largo de la novela mediante un lenguaje que es, al mismo tiempo, fálico y militar, como ar- 
mas agresivas, inquebrantables, conduciendo un penoso ataque a todo lo que es tierno. El señor Gradgrind es "un cañón cargado hasta el hocico de hechos", un "aparato galvanizante», dirigido contra "las jóvenes y tiernas imaginaciones que habían de ser barridas por la tormenta» (p. 48). Por el contrario, el acercamiento de la fantasía es retratado como delicada y tiernamente sensual, como encantador tanto en la destreza del discurso y el gesto, como en el intrincado ritmo y la textura de las palabras mismas. EI lenguaje de Gradgrind suena duro, intrusivo, su cadencia fiera y abrupta. Como lenguaje, su cuerpo se mueve con un penoso modo directo, combinando la agresividad con una complacencia farisaica: "La escuela $\mathrm{M}^{\prime} \mathrm{Choa-}$ kunchild era todo hechos, y la escuela de diseño era todo hechos, y todo eran hechos entre la cuna de la Maternidad y el cementerio, y lo que no pudiera reflejarse en cifras o demostrarse apto para su compra en el más barato de los mercados y su venta en el más caro, no existía, ni debía jamás existir, por los siglos de los siglos, amén" (p. 66). Por el contrario, el discurso de la Fantasía tiene, por así decirlo, un cuerpo circense, acrobático y flexible. Adora la textura física del lenguaje y juega con ella, tocando y acariciando al lector. Incluso cuando habla de sus adversarios, no puede contenerse a sí misma por mucho tiempo para tratarlos de manera juguetona y casi tierna, como compañeros de juego, en donde el placer se disfruta por sí mismo. De este modo pueden explicarse los muchos juegos lingǘsticos aliterados en la descripción de la casa de Gradgrind, mientras el narrador disfruta el juego de su discurso flexible acerca de sus cuerpos embotados, como en este pasaje en donde una descripción, inicialmente directa, da paso a una más y más sensual, hasta que el juego de la lengua termina por apropiarse, venciendo a su propio objeto:

Los pequeños Gradgrind también disponían de salas para varios departamentos de la ciencia. Disponían de una sala de conquiliologia y una sala pequeña para metalurgia y una sala pequeña para mineralogia; y todos los especímenes estaban ordenados y catalogados, y las muestras de las piedras y los minerales parecía que acababan de ser cortadas de las sustancias madres por esos instrumentos tan tremendamente duros que eran sus propios nombres; y para parafrasear la leyenda de Peter Piper, el cual nunca hubo de entrar en sus habitaciones, «Si los avariciosos nin̄os Gradgrind aspiraban a poseer algo más, ta qué, por amor de Dios, aspiraban los avariciosos niños Gradgrind?» [p. 55].

Aquí la imaginación literaria opone, a los duros instrumentos de los nombres usados por la economía política, su propio y distintivo lenguaje, y se deja llevar por su juego sensual. No permanece en la cuestión ni se mueve inquebrantablemente hacia su meta. Incorpora deliberadamente formas de deseo y sensualidad profundamente opuestas a aquellas que atribuye a la economía política. Imaginad el lenguaje como una manera de tocar el cuerpo humano, sugiere Dickens, y tendréis un buen modo de 
hacer un escrutinio de las pretensiones de la economía política acerca de servir a toda la complejidad de nuestro ser.

(Debería añadir aquí que Dickens ha sido presentado a veces como un represor de la sexualidad, especialmente de la sexualidad femenina. Personalmente, creo que esta interpretación no puede sostenerse si examinamos de cerca el retrato que pinta la novela acerca de los modos en que la lengua y la mente adquieren una forma humana. No sólo se condena la agresividad burda mientras se celebra una sexualidad más variada, más jovial, más gentil, sino que es evidente que este juego sensual está ligado, constantemente, a la influencia de lo femenino. Lo que ya he sostenido en otra parte acerca de la feminización dickensiana del autor/narrador en los contextos eróticos, viene aquí muy a propósito: la parte de la vida susceptible, juguetona, la parte, dice David Copperfield, que la mayoría de los hombres adultos ha perdido, es la parte de la que se generan las novelas..$^{35}$ Esta novela no es, claramente, una excepción.)

Y con esta mención al juego, llegamos a otro elemento relevante acerca de la Fantasía, el cual debemos ahora explorar para completar nuestro análisis acerca de su función social. Cuando un niño aprende a fantasear, está aprendiendo algo inútil. Ésta es la mayor objeción que pone la escuela de Gradgrind: los libros de cuentos son "fútiles». Lo que necesitamos son hechos, «la única cosa necesaria" y ¿qué uso puede uno obtener del hombre en la luna? Pero el niño que se deleita con historias y canciones infantiles está adquiriendo la idea de que no todo en la vida humana tiene un uso. Está aprendiendo un modo de interactuar con el mundo en que el acento no está puesto exclusivamente en la idea de uso, sino que es capaz de atesorar cosas por ellas mismas. Y esto también es válido para sus relaciones con otros seres humanos. No es sólo la capacidad de dotar a una vida de forma lo que hace a la imaginación metafórica moralmente valiosa, sino la capacidad de ver lo que uno construye en su fantasía como algo que no sirve otro propósito salvo sí mismo, algo bueno y maravilloso sólo por sí mismo. El juego y la diversión, por lo tanto, no son simplemente complementos o apéndices de la vida humana, sino ejemplos de un modo crucial de ver los elementos esenciales de la vida. En este sentido, en esta novela el placer del lector tiene otra dimensión moral más, que, de hecho, le permitirá prepararse para actividades morales de muchas otras clases en la vida. ${ }^{36}$

Podemos, tal vez, hacer un sumario contrastando los dos ejemplos de educación que se encuentran en los dos epígrafes de este ensayo. Ambas son escenas en que se pide la definición o explicación de algo. En la primera, tenemos la respuesta al ortodoxo Gradgrind dada por su alumno Bitzer. El segundo pasaje no es, por supuesto, de Dickens sino del poema "Canto de mí mismo" de Walt Whitman. No voy a pretender haberlo escogido simplemente por el hecho de que sirve perfectamente de contraste 
con la definición de Gradgrind y porque está muy cerca del espíritu de la novela de Dickens, aunque coincida con ambas razones. De hecho, lo dispuse de este modo para poder tener una excusa para discutir dicho poema en este argumento que es tan dickenseniano, porque me encanta y lo encuentro muy bello. Tal vez este desvío al estilo circense del camino recto de mi exposición pueda parecer que mantiene el espíritu de mi argumento.

Bitzer no ha amado nunca un caballo, ni tiene interés en pensar cómo serían las cosas si él fuera uno. Con aire de finalidad y certeza, recita la fría descripción externa. El caballo surge como una máquina útil sin más. Qué diferente es el orador de Whitman. En primer lugar, está motivado no por una enumeración mecánica que ha de ser completada, sino por la curiosidad real del niño, y por la vista y el tacto de la hierba en la cual yace mientras habla. Su primera respuesta es la de reconocer que no sabe de manera definitiva lo que es; es decir, reconocer un misterio de la naturaleza. Todas sus consiguientes respuestas se presentan como suposiciones. Comienza hablando de su vida interior, sus esperanzas; luego, caprichosa y en absoluto dogmáticamente, de la idea de Dios que tiene un niño; luego le dice al niño que la hierba es como él, un trozo joven de vegetación; le pide al niño que la vea cono si fuera él mismo. Más adelante le enseña al niño que puede también tener un significado social: ya que uno puede contemplarla en la igual vitalidad y dignidad de todos los norteamericanos, sus derechos y privilegios iguales, por encima de las diferencias raciales y étnicas. Luego, volviéndose (suponemos) hacia sí mismo, el orador ve en la hierba una serie de significados más oscuros, reflexionando sobre ella y a través de ella acerca de la belleza de los hombres muertos. Confiere belleza incluso a los cadáveres bajo tierra, y habla de ellos con una reverencia y una ternura profundamente eróticas, pero de un modo que no excluye otros pensamientos acerca de la hierba (como algo que proviene de padres ancianos, o niños muertos prematuramente). Y, aún asi, en la oscuridad de la hierba (demasiado oscura como para provenir de las ancianas madres, o incluso de las bocas de aquellos a los que ha querido o habría podido querer), ve una imagen de su propia muerte.

Aquí vemos todas las capacidades que tiene la fantasía hábilmente entretejidas: su capacidad para conferir a una forma percibida un significado más rico y complejo; su construcción generosa del mirar; su preferencia por el asombro en vez de por las soluciones ufanas; sus movimientos sorprendentes y joviales, encantadores por sí mismos; su ternura, su erotismo, su asombro ante el hecho de la mortalidad humana. Es la opinión de Dickens, así como la de Whitman, que esta imaginación (incluyendo su jovialidad y su erotismo), es la base necesaria para gobernar adecuadamente un pais de ciudadanos libres e iguales. Ya que, como Whitman escribe en otro texto, el artista literario "ve la etemidad en los hombres y las mujeres, no ve a los hombres y mujeres como sueños o puntos". ${ }^{37}$ Con 
caridad, la Razón es beneficiosa; está dirigida por una visión generosa de sus objetos. Sin ella, la Razón es fría y cruel..$^{38}$

Ahora podemos entender que la persistente abundancia de la metáfora en el lenguaje de Tiempos dificiles no es un mero juego de diversión estilística. Va directamente al centro del tema moral de la novela. Incluso cuando la novela describe el aula de Gradgrind, no puede evitar comparar una cosa con otra, ver una cosa en otra: dos cavernas oscuras en los ojos del señor Gradgrind; un bosque de abetos por pelo; la corteza de una tarta de ciruela en la calva superficie en lo alto de su cabeza (p. 47). Incluso cuando describe la monótona y mortalmente aburrida fábrica de Coketown, triunfa mediante el lenguaje, comparando las columnas de humo a serpientes, las partes móviles de las máquinas a uelefantes enfermos de melancolía», demostrando de esta forma el significado humano de lo inhumano. La novela no puede describir su oposición a algo sin luchar contra ello, aproximándose desde la fantasía y superándolo jovialmente. ${ }^{39}$

He de subrayar a estas alturas que en la novela ( $y$ desde mi punto de vista) no hay disparidad de la razón o de la búsqueda científica de la verdad. Lo que estoy criticando es una pseudo-ciencia que pretende defender la verdad y la razón. Falla en defender la verdad en tanto en cuanto confunde dogmáticamente la complejidad de los seres humanos y de la vida humana. Falla en defender la razón cuando confía a ciegas en percepciones incompletas y teorías psicológicas burdas para no complicar sus elegantes modelos. La novela no habla de rechazar a la razón, sino de llegar a ella mediante una vía que ha sido iluminada por la fantasía, que se ve aquí como una facultad creativa y verídica. La alternativa que yo propongo no es el circo de Sleary. El circo ofrece al lector metáforas esenciales del arte, la disciplina, el juego y el amor, pero incluso dentro de la novela sus actitudes se presentan como políticamente incompletas, demasiado fantasiosas como para gobernar una nación. La novela nos ofrece una alternativa: ella misma, en su compleja combinación de descripción cualitativamente rica y reflexión social crítica. Indica, además, que los tratados políticos y económicos de un tipo más abstracto o matemático podrían ser perfectamente consistentes con este propósito, siempre que el concepto de ser humano contenido en esos tratados fuera el más rico del que se dispusiera en la novela; es decir, siempre que no perdieran de vista lo que por mor de la eficiencia están omitiendo. El gobierno no puede investigar la historia de la vida de cada ciudadano del modo en como hace la novela con sus personajes. Puede, sin embargo, saber que cada ciudadano tiene una compleja historia de este tipo, y puede ser consciente de que la norma, en principio, debería reconocer la separatividad y diferencia cualitativa de cada uno, igual que hace la novela.

De un modo particular, la novela como género está fuertemente en consonancia con cierta norma de racionalidad: nominalmente, en su insis- 
tencia en el rol fundamental, en su propia construcción de una noción general del ser humano. La descripción de la biblioteca de Coketown habla de «naturaleza humana, pasiones humanas, esperanzas y miedos humanos» como la cuestión central de la novela. Al hacer eso, nos recuerda que la novela no centra su atención en el contexto social y en la variedad individual a costa de poner en peligro cierto sentido de la comunidad humana. Forja una relación compleja con su lector en donde, por una parte, al lector se le insta a preocuparse por los rasgos concretos de circunstancia e historia, y a considerarlos relevantes para la elección social. Pero, por otra, se le insta siempre a reconocer que los seres humanos (aun en sus distintas esferas), tienen pasiones, esperanzas y miedos comunes: la necesidad de enfrentarse al misterio de la muerte, el deseo de aprender, de profundizar los lazos de familia. Se dirige explícitamente a su lector hipotético como a alguien para quien la esfera de la vida es diferente de la del autor, con posibilidades y oportunidades concretas diferentes. $\mathrm{Y}$, sin embargo, se da por sentado que el lector puede, no obstante, identificarse con los personajes y acontecimientos de la novela como posibilidades para la vida humana en general, así como pensar de qué manera podrían «tales cosas" contribuir en la vida de él o ella. ${ }^{40}$ Este movimiento complejo de la razón y la imaginación, de lo concreto a lo general y vuelta a lo concreto mediante la compasión y la identificación, está construido dentro del género, como Tiempos dificiles establece de manera correcta. Y en la vida real uno es consciente de que los trabajos de la imaginación literaria son, frecuentemente, más bien agentes reflexivos flexibles y versátiles que cruzan los límites culturales, en lugar de tratados filosóficos con sus ataduras temporales, culturales, sus términos artísticos, su constante falta de compromiso con los miedos y las esperanzas de todo el mundo.

En su compromiso con una noción general del ser humano, esta novela (como muchas otras) es, a mi modo de ver, si bien particularista, en modo alguno relativista. Esto es, reconoce necesidades humanas que trascienden los límites de tiempo, lugar, clase, religión y grupo étnico, y pone en el centro de su reflexión moral la cuestión de su adecuada resolución. Su criticismo de situaciones políticas y económicas concretas yace en la noción de lo que es para un ser humano prosperar, y esta noción, en sí misma, aunque extremadamente general y necesitada de mayores especificaciones, no es ni local ni sectaria. Por otro lado, parte del contenido de la idea de prosperidad es un profundo respeto hacia la diferencia cualitativa, de manera que la norma entiende que los gobiernos, sean como sean, han de atender a los ciudadanos en todas sus variedades y concreciones, y deberian responder, de una manera sensible, a las contingencias particulares, históricas y personales. Pero la cuestión es que se trata de un mandato universal y una parte del cuadro universal de lo humano. Y es confiando en este ideal universal que la novela (tan diferente a una guía o a un 
informe antropológico), hace que la lectora participe en las vidas de personas muy diferentes a ella y también que se convierta en una crítica de las distinciones de clase que hace que personas construidas de una manera similar tengan un acceso desigual a la prosperidad. ${ }^{41}$ De este modo, la novela es, desde mi punto de vista, en su estructura y su aspiración, una defensora de los ideales ilustrados de la igualdad y la dignidad para toda forma de vida humana, no del tradicionalismo o el parroquialismo. Se opone a la perversión de ese ideal en el nombre de la seudociencia de la economía, y también a toda aplicación insensible de este ideal que no respete suficientemente las historias que se cuentan en un contexto histórico concreto (pero no se opone, especificamente, al ideal mismo).

\section{La lección de economía politica de Sissy Jupe (y la muestra)}

¿Qué significado tiene todo esto para la economía política? He de concluir haciendo referencia a mi propia formación en dicha ciencia, en la cual no soy mejor alumna de lo que lo es Sissy Jupe. En los últimos cinco años he estado asociada con el World Institute for Development Economics Research, Instituto de investigación de la Universidad de las Naciones Unidas, cuya finalidad es la de explorar aproximaciones interdisciplinares a los problemas económicos de los países en vías de desarrollo. He sido consejera de investigación de un proyecto que discute cómo se podría uno medir la "calidad de vida» de los países en vías de desarrollo. ${ }^{42}$ Éste es, de hecho, el tema central de la primera lección de Sissy Jupe en economía política, y mi interés en la novela de Dickens creció notablemente debido a que aún hoy la novela se corresponde, en gran medida, con una gran parte de la práctica de economía del desarrollo y la gestión política pública que se basa en ella.

Éste es el proceder (antes como ahora) de la escuela Gradgrind (Sissy le cuenta a Louisa):

«Y dijo, "Bien, imaginad que este aula es la Nación. Y que en esta Nación hay cincuenta millones en dinero. $\dot{i}$ No es acaso ésta una nación próspera? Niña número veinte, ¿no es ésta una nación próspera, y no está usted nadando en la abundancia?"."

"¿Qué le dijiste tú?" preguntó Louisa.

«Señorita Louisa, le dije que no lo sabía. Pensé que no podía saber si la nación era próspera o no, y si yo estaba nadando en la abundancia o no, a no ser que supiera en manos de quién estaba el dinero, y si parte de él fuera mío. Pero eso nada tenfa que ver con el asunto. No aparecía en los números», dijo Sissy enjugándose las lágrimas.

"Cometiste un gran error», observó Louisa [p. 97].

En nuestros dias, de hecho, cuando se analiza la prosperidad de los países en vías de desarrollo en aforma tabular», la estrategia más común 
es, sin lugar a dudas, enumerar simplemente el PIB per cápita. ${ }^{43}$ Esta fría medida, como por supuesto reconoce Sissy inmediatamente, ni siquiera habla del modo en que está distribuida la riqueza y la ganancia. Ni mucho menos habla tal enfoque (que se circunscribe exclusivamente a lo monetario), de los seres humanos que tienen o no el dinero para funcionar en las distintas actividades que se consideran relevantes para la vida humana. Ni siquiera nos habla de las expectativas de vida, ni de la mortalidad infantil, mucho menos acerca de la salud, la educación, el funcionamiento de la política, la calidad de las relaciones raciales, étnicas y de género.

Un acercamiento ligeramente más sofisticado mide, como Gradgrind desearía, la utilidad media o total de la población, combinando satisfacciones. Este enfoque tiene, al menos, la ventaja de ver directamente cómo funcionan los recursos para las personas, al promover objetivos humanos de varias clases. Pero tiene un inconveniente que la novela hace destacar de un modo clarísimo: ignora el hecho de que los deseos y las satisfacciones son altamente maleables y que las personas que son muy pobres pueden adaptarse a las circunstancias en las que viven; es decir, que una de las peores partes acerca de la privación casi absoluta es que roba a la gente las aspiraciones e insatisfacciones que van unidas irremediablemente al sentido de la dignidad y de la que en base a ella es justo demandar. ${ }^{44}$ Las Manos en la fábrica de Coketown manifiestan cierto descontento; pero dado el cansancio terrible, las limitaciones materiales y de imaginación bajo las cuales trabajan, parecen dispuestos a darle la bienvenida a cualquier pequeña compensación $\mathrm{y}$, debido a que aún no han sido capaces de articular el ideal de completa igualdad, aceptan unos líderes inadecuados e insensibles. Stephen puede ver que su vida es "un caos", pero no puede articular claramente la naturaleza de su descontento, o sentir su fuerza totalmente. Gradgrind, por otra parte, se siente plenamente satisfecho con su vida, a la que la novela muestra como espiritualmente empobrecida. Su descontento al final de la novela es, claramente, un progreso con respecto a su ecuanimidad inicial. En el límite entre ambos, el personaje de Bitzer nos enseña a desconfiar del sentimiento de satisfacción cuando no está ligado a ninguna otra valoración ética; ya que lo que quiera que haga que ese "vaso medio vacío del egoísmo" [Bitzer] se sienta satisfecho, llenará al lector de escalofríos de ansiedad e incluso horror. $\mathrm{Y}$ sabemos desde el principio que existe más valor, más humanidad en la pobreza y precariedad de Sissy Jupe (un barómetro hipersensible de injusticias e hipocresías), que en la vacía autocomplacencia de Bitzer. «Así como la niña tenía los ojos y el cabello tan oscuro que parecían recibir del sol un color más profundo y brillante, el niño era de ojos y pelo tan claro, que los mismos rayos parecian robarle el poco color que había en él» (pp. 49-50). Con esta elocuente descripción simbolica, la novela quiere expresar la riqueza humana de la respuesta a la vida de Sissy, incluyendo su infelicidad, y la 
glacial mecánica cualidad del optimismo de Bitzer. ${ }^{45}$ ¿Puede la utilidad darnos la medida de estas vidas, de la educación de la que son fruto, del funcionamiento humano que contienen y del que no?

Tal criticismo de la utilidad como medida (junto a los otros puntos que he mencionado sobre diferencias cualitativas y agregación, que han sido muy subrayados en recientes críticas filosóficas de la economía), han llevado a un grupo de economistas y filosofos, del que formo parte, a defender un acercamiento a la calidad de vida basada en la noción de funcionamiento humano y capacidad humana, en vez de en la opulencia o la utilidad. (En este enfoque ha sido pionero dentro de la economía Amartya Sen, quien también es un filósofo, y tiene más simpatizantes dentro de la filosofía que dentro de la economía hasta el día de hoy.) La idea es la de averiguar cómo le va a la gente, preguntando cómo su forma de vida les ha ayudado a funcionar en diversas áreas, incluyendo, aunque no exclusivamente, la movilidad, la salud, la educación, la participación política y las relaciones sociales. Este acercamiento no quiere acabar con una única cifra, reduciendo así la cualidad a la cantidad, e insiste en preguntar las capacidades funcionales reales de cada individuo, cualitativamente distinto y separado, en vez de preguntarse simplemente acerca de las cantidades que un individuo requiere en base a los recursos de que se dispone. Esto es así debido a que este enfoque reconoce que los individuos necesitan diferentes cantidades de recursos para llegar a un nivel parecido de funcionamiento: la persona incapacitada necesita más recursos para su mobilidad que una persona corriente. Una persona muy activa o mayor, necesita más comida que una sedentaria o menor, etc. ${ }^{46}$ De cualquier forma, este acercamiento permite, realmente, hacer mediciones y crear modelos: como cuando, por ejemplo, uno estudia el acceso que las personas impedidas físicas tienen o no a funciones de diversos tipos en una sociedad dada. O como cuando uno estudia las diferentes necesidades alimenticias de las personas de distintas edades, tamaños y ocupaciones. O como cuando uno estudia los modos en que las diferencias de clase obstaculizan el acceso a la participación política. Los gobiemos de Finlandia y Suecia usan, de hecho, tales medidas basadas en la cualidad plural para analizar las desigualdades en la población, demostrando así que estas mediciones resultan viables. ${ }^{47}$ Tales medidas serán ciertamente plurales y no únicas, diversas cualitativamente en vez de homogéneas. Lo que sostenemos es que esto las hará mejores, no peores.

Lo que quiero afirmar ahora es que una novela como ésta es un paradigma de tal valoración. Presentando la vida de la población con una rica variedad de distinciones cualitativas y de descripciones individuales complejas, acerca del funcionamiento y de sus impedimentos en contextos concretos, la novela provee la clase de información que tal valoración requiere, y envuelve al lector en la tarea de elaborar, precisamente, tal valoración. De este modo, despliega una clase de paradigma imaginativo para 
el trabajo público en esta esfera, al que debería comprometerse cualquier modelo más cuantitativo y simplificado.

Tiempos dificiles acaba invocando a uno de sus personajes más importantes: «Querido lector! Está en nuestras manos el que en nuestros dos ámbitos de acción ocurran o no cosas como éstas. ¡Deja que ocurran! Nos sentaremos con nuestros corazones más ligeros, para contemplar las cenizas de nuestros fuegos cómo se tornan frías y grises» (p. 314). Dirigiéndose al lector como a un amigo y agente cómplice, si bien en una esfera diferente de esta vida, la voz del autor dirige el asombro compasivo del lector ante el destino de sus personajes hacia sí mismo o hacia sí misma, recordándole que también ella se dirige hacia la muerte; que también ella tiene sólo esta oportunidad de contemplar en el fuego las formas de la fantasía, y lo que éstas pueden sugerir para mejorar la vida humana. La novela tiene razón: está en nuestras manos que tales cosas sucedan o no. Sostengo con ello que no es como utilitaristas económicos sino como lectores de novelas como deberíamos aproximarnos a las opciones sociales de que disponemos, tratando, antes de que nos llegue la muerte, de considerar a nuestros conciudadanos, a los otros seres humanos, con el asombro y la generosidad que esta imaginación promueve. ${ }^{48}$

\section{NOTAS}

Este ensayo es una versión revisada de un trabajo que presenté dumnte el programa de «Distinguished Scholars» en el Commonwealth Center. Este trabajo es la primera de tres conferencias Alexander Rosenthal impartidas en la Escuela de Derecho de Northwestern University en abril de 1991. Quisiera agradecer a la Escuela de Derecho el permitirme publicarla aquí, adelantándome a su publicación ( $y$ revisión) en un libro que estará basado en las tres. Estas conferencias, en conjunto, llevan por título "La imaginación literaria en la vida pública". La segunda conferencia investiga, por una parte, el papel que juegan las emociones en la experiencia literaria, y por otra, la racionalidad pública. La tercera conferencia describe una norma de juicio legal basada en $\mathrm{cl}$ análisis de la racionalidad de las dos primeras conferencias, mostrando sus implicaciones para concepciones de neutralidad judicial, la regla del derecho y ciertas áreas de interpretación constitucional.

1. Todas las citas de Tiempos dificiles proceden de la edición [inglesa] de Penguin [Harmondsworth, 1969], editada por David Craig. Los estudios sobre esta novela que más me han influido son los de Raymond Williams en Culture and Society [Londres, 1958], I, cap. 5, la excelente introducción de David Craig a la edición de Penguin, así como la obra de F.R. Leavis The Great Tradition [Nueva York, 1948].

2. Ver Martha C. Nussbaum, Love's Knowledge: Essays on Philosophy and Literature [Nueva York, 1990]; especialmente los articulos "The Discernment of Perception", pp. 54-105 y "Perception and Revolution", pp. 195-219.

3. Compánese la descripción de la actividad del lector en la obra de Wayne Booth, The Company we Keep: An Ethics of Fiction [Berkeley, 1988]; el recuento de los modos en que las narrativas incorporan las formas del deseo en la obra de Peter Brooks, Reading for the Plot [Nueva York, 1984]; así como la descripción del reconocimiento del lector en la obra de Stanley Cavell, The Claim of Reason [Nueva York, 1979], IV.

4. En la actualidad, «economía polítican es un término que emplean (como autodescrip- 
ción), en principio, los economistas más críticos y filosóficos, como por ejemplo, Amartya Sen. De modo que lo que estoy criticando aquí no es lo que el término indica en su acepción contemporánea.

5. Por ejemplo, ver las obras de James Griffin, Well-Being [Oxford, 1986], y Richard B. Brandt, A Theory of the Good and Right [Oxford, 1979].

6. Ver, principalmente, los trabajos de Richand Posner, incluyendo Economic Analysis of Law [Boston, MA, 1977], The Economics of Justice [Cambridge, MA, 1988], y Law and Litera* ture: A Misunderstood Relation [Cambridge, MA, 1988]. En The Problems of Jurisprudence [Cambridge, MA, 1990] Posner ha cambiado su orientación para abrazar un cierto tipo de «pragmatismon. Una buena crítica general del razonamiento económico en la vida pública es la introducción de Utilitarianism and Beyond editada por Amartya Sen y Bernard Williams [Cambridge, 1988].

7. Ver la obra de Barbara Hernstein, Smith Contingencies of Value [Cambridge, MA, 1988].

8. Ver las obras de Posner, Economic Analysis of Law y The Economics of Justice, y de Gary Becker. The Economic Approach to Human Behavior [Chicago, 1976] y A Treatise on the Family [Cambridge, MA, 1981]. Especialmente ilustrativo es el principio de The Economics of Justice, en donde por primera vez Posner introduce «el supuesto de que las personas son maximizadores racionales de sus satisfacciones», subrayando que alos principios de la economía son deducciones de este supuesto" (y luego continúa usando el término amaional», sin mayores argumentos filosoficos, como si realmente quisiera dar a entender "maximizadores de satisfaccionesw), ver pp. 1-2. Una crítica incisiva a Posner, a propósito del valor de la integridad personal de uno, aparece en el artículo de Margaret Jane Radin, «Market-Inalienability", Harvard Law Review, 100 [1987], pp. 1.849 y ss.

9. Algunas de estas críticas pueden aplicarse también a los utilitaristas filosoficos, muchos de los cuales creen que los valores se pueden medir mediante una única cifra estándar. Ver, por ejemplo, el articulo de James Grifiin, *Are There Incommensurable Values?, Philosophy and Public Affairs, 7 [1977], pp. 34-59, criticado en el articulo de Nussbaum *The Discernment of Perception.

10. Los trabajadores se quejan de que sus vidas están constreñidas por una emismidad» que les ha sido impuesta (180); por una ausencia de variaciones cualitativas. No es sorprendente que una teorfa inclinada a eliminar las distinciones cualitativas, los trate de este manera.

11. Ver un buen análisis de este rasgo en la introducción a Utititarianism and Beyond, de Sen y Willians.

12. Poco después, tras escuchar las desgracias de Stephen, Louisa señala que ya las había oído mencionar antes, «si bien no atendió a los detalles en aquella ocasión» (p. 188).

13. Otro ejemplo de burda creación de ficción de orden económico son los raburridos libritos [...] en donde los niños bien criados acaban llevando su dinero, invariablemente, a la caja de ahorros, mientras que los niños mal criados acaban, invariablemente, deportados como castigon (p. 90).

14. Que esto no sea una mera ficción puede confirmarse leyendo la obra de Becker $A$ Treatise on the Family.

15. Contrastar esto con la página 241 , en donde Louisa entiende ahora que su matrimonio falló «por todas esas causas de disparidad que surgen de nuestras dos naturalezas individuales, y que ninguna ley general podrá gobemar o establecer por mi, hasta que no puedan decirle al cinjajano en dónde meter el cuchillo para descubrir los secretos de mi alma*.

16. Esto está en la raiz de los motivos que existen tras el utilitarianismo en general, e inspira muchas de las desviaciones deliberadas de la creencia común. Henry Sidgwick, por ejemplo, aceptando que adoptar una única medida de elección es alejarse de la creencia común, escribe: «Si no hemos de sistematizar las actividades humanas tomando la Felicidad Universal como su fin último, ten qué otro principio hemos de sistematizarlas?", y subraya que tales desviaciones se encuentran siempre que surge una ciencia (Methods of Ethics, 7.7 ed. [Londres, 1907], pp. 401, 406, 425). 
17. Justo un poco antes de oír hablar acerca de los «pesados libritos", el narrador mismo describe a la gente de Coketown como si "caminaran contra el tiempo hacia el mundo infinitow (p. 90).

18. Para una crítica y un material incisivo acenca de estas presuposiciones conductistas ver el artículo de Amartya Sen, «Rational Fools», Philosophy and Public Affairs, 6 (1976-77). pp. 317-344.

19. Ciertamente. Si tenemos en cuenta que una de las pretensiones centrales del utilitarismo es la de que se toma en serio el sufrimiento de los pobres, entonces vemos que la novela ofrece, además, una devastadora crítica interna. Desarrollo esta idea un poco más en la segunda de las conferencias Rosenthal.

20. Al mismo tiempo, la particular concepción de la ciencia que poseen los utilitaristas le debe algo a la concepción cartesiana de la naturaleza como máquina; esto aparece más claramente en las actitudes hacia los animales cn el aula de Gradgrind.

21. Este es un modo de interpretar a Bitzer; pero uno también podría preguntarse acerca de śl: sí es un hipócrita, manipulando la educación que ha recibido para servir a sus propios intereses. De este modo, la curiosidad inspirada por la novela le mueve a uno a tratar de humanizar incluso a los caracteres más inhumanos.

22. La participación emocional del lector se discute en la segunda conferencia Rosenthal.

23. Ver la obra de Ian Watt, The Rise of the Novel [Berkeley, 1957] y la de Charles Taylor, Sources of the Self: The Making of Modem Identity [Cambridge, MA, 1989].

24. Ver en este sentido la magnifica discusión de David Craig en la Introducción a la edición de Penguin.

25. Esto no quiere decir que nunca pudiera existir una novela desigualitaria, sino que la desigualdad está en tensión con la estructura del género, la cual invita a preocuparse y a respetar cualquier historia a la que el lector diriga su atención. Ver tambien The Rise of the Novel de Watt y The Sources of the Self de Taylor.

26. Ver tambiên la página 238, en donde el señor Gadgrind muestra cómo "el Buen Samaritano era un Mal Economista»,

27. De esta manera, la novela construye, en su lector imaginado, un juez moral ideal que posee cierto parecido a las partes en la Posición Original de John Rawls (A Theory of Justice [Cambridge, $M \Lambda_{s}, 1971$ ]). Pero las facultades que se sugiere que el lector emplee no corresponderían al análisis de Rawls del «juicio consideradon. Sobre esto, ver aPenceptive Equilibrium*, en Love's Knowledge de Nussbaum.

28. Por consiguiente la novela también incorpora una concepción (bastante aristotélica) del placer, por la cual el placer en sí mismo contiene distinciones cualitativas y tiene lugar en actividades de diferentes clases.

29. El utilitarista pretende estar maximizando el placer. ¿Por qué entonces se opone tanto a la lectura de novelas? La fuente de la oposición es el miedo del señor Gradgrind a que este tipo de lecturas haga que la gente se comporte de maneras ineficaces para el resto de sus vidas. Así, desde su punto de vista, hará más daño que beneficio.

30. Ver página 240 , donde Louisa contrasta la percepción de alas formas y superficies de las cosas* con el ejercicio de la fantasia.

31. Sobre esto, ver el articulo de Richard Wollheim "Seeing-In and Seeing-As», en Art and Its Objects, 2." ed. [Cambridge, 1980], así como e] segundo capítulo de Painting as an Art [Princeton, 1987], cap. 2.

32. Ver el maravilloso análisis de este tema en la obra de Cavell The Claim of Reason, parte IV.

33. Ver página 77, donde se dice de la gente del circo que «merecen" tanto arespeto" como una "construcción generosa"; y también la famosa máxima de Sleary "iMiraz lo mejor de nozotroz mizmoz, no veáiz lo peor!" (p. 83).

34. Ya que forma parte de la pretensión de la novela la idea de que el modelo económico simple no predice, en realidad y de manera fidedigna, cómo se comporta la gente. Sus formulas no son siquiera útiles en ese sentido. Ver el artículo de Sen «Rational Fools». 
35. Ver "Steerforth's Arm", en Love's Knowledge de Nussbaum. Esto no significa, por supuesto, que Dickens esté libre de contradicciones en este punto, como el tratamiento de Emily viene a demostrar. Pero en esta novela es importante observar que la parte representativa de la imaginación artística, Sissy Jupe, es también el túnico personaje que tendrá un matrimonio feliz y amable.

36. En la segunda conferencia Rosenthal exploro las operaciones morales del lector aún más, centrándome en la conexión entre la fantasía y las emociones de amor y agradecimiento.

37. Walt Whitman, "By Blue Ontario's Shore», 1, 153, en Walt Whitman: The Complete Poems (ed. de Francis Murphy) [Harmondsworth, 1975], p. 369.

38. Uno podría preguntarse, naturalmente, cpero no puede emplearse la fantasía para odiar? Profundizo más este punto en la segunda conferencia, cuando hablo del abanico de sentimientos a los que se anima al lector y a los que no, en virtud de la forma de la novela. Conecto este análisis con el ideal de espectador emocional de Adam Smith. Tiempos dificiles nos urge a que consideremos, en primer lugar, la participación sin prejuicios de la novela en toda y cada vida. Segundo, su reconocimiento de que cada vida tiene su propia historia, $y$. finalmente, su invitación a que veamos cada vida desde el punto de vista de la persona. Aquí, creo, vemos lo que Dickens quiere decir por ugran Caridad en el corazón»: la novela, aun cuando permite e incluso sugiere cierto criticismo hacia sus personajes, promueve a la compasión mediante la invitación a la comprensión empática.

39. Compárese al señor Gmdgrind en las páginas 242-244, en donde es capaz de ver cierto fuego en los ojos de Lonisa y comienza a hacer uso del discurso metafórico.

40. Más acerca de esto puede verse en los artículos de Nussbaum "Aristotelian Social Democracy», en Liberalism and the Good, editado por R. Bruce Douglas, Gerald M. Mara y Henry S. Richardson [Nueva York, 1990], pp. 203-252; *Aristotle on Human Nature and the Foundations of Ethicsn, en un volumen en honor a Bemard Williams editado por Ross Hanison y J.E.G. Altham, que aparecerá en Cambridge en 1991; y uHuman Functioning and Social Justice: In defense of Aristotelian Essentialism», ensayo leído ante el Institute for Humanities de la Universidad de Chicago (que aparecera en Political Theory).

41. Ver las obras de Amartya Sen Choice, Welfare, and Measurement [Oxford, 1982]; Resources, Value and Development [Oxford, 1984]; Commodities and Capabilities [North-Holland, 1985]; The Standard of Living [Cambridge, 1987].

42. Ver The Quality of Life editado por Martha Nussbaum y Amartya Sen [Oxford, 1991].

43. Hasta cierto punto, y en algunos contextos, ha habido intentos de hacer otto tipo de enfoques en base a mecesidades básicas" o, como el enfoque reciente de Sen, en base a funcionamiento y capacidad. Pero, en conjunto, esta expresión permanece, y de qué manera. Ver la obra de Sen, Resources, Value and Development, y la introducción a la de Nussbaum y Sen, The Quality of Life.

44. Ver las obras de Sen Choice, Welfare, and Measurement, y The Standard of Living.

45. Ver el análisis de Leavis de este pasaje en The Great Tradition.

46. Ver las obras de Sen Choice, Welfare and Measturement y The Standard of Living, asi como su artículo "Capabilities and Well-Being" en el libro de Nussbaum y Sen.

47. Ver los trabajos de Robert Erikson y Erik Allardt en el libro de Nussbaum y Sen.

48. Esta conferencia fue impartida en el Commonwealth Center en noviembre de 1990. Estoy muy agradecida a Ralph Cohen y al Center por la oportunidad que me han otorgado al permitirme discutir mi trabajo en curso. Estoy muy agradecida también a Dan Brock, Kenneth Dornstein, Elliott Dunn, Jean Hampton, Linda Hirshman, Amartya Sen y Cass Sunstein, los cuales hicieron comentarios que han contribujdo a mis revisiones. 